\title{
İşgalden İhtilale Millî Mücadele Hareketinin Diplomatik Boyutu
}

\section{Diplomatic Dimension of National Struggle Movement from Occupation to Revolution}

\author{
Tekin ÖNAL ${ }^{1}$
}

'Sorumlu yazar/Corresponding author: Tekin Önal, (Dr. Öğr. Üyesi),

Ankara Yıldırım Beyazıt Üniversitesi, İnsan ve

Toplum Bilimleri Fakültesi, Tarih Bölümü,

Ankara, Türkiye

E-posta: tekin_onal@hotmail.com

ORCID: 0000-0002-8746-1445

Başvuru/Submitted: 28.08.2019 Revizyon Talebi/Revision Requested: 10.09.2019

Son Revizyon/Last Revision Received: 25.09.2019

Kabul/Accepted: 10.11.2019

Online Yayın/Published Online: 28.11.2019

Atıf/Citation: Onal, Tekin. "işgalden Ihtilale Millî Mücadele Hareketinin Diplomatik Boyutu." Türkiyat Mecmuası-Journal of Turkology, 29, 'Milli Mücadele' Özel Sayısı (2019): 89-125.

https://doi.org/10.26650/iuturkiyat.652128 öz

Osmanlı Devleti için Birinci Dünya Savaşı 30 Ekim 1918 tarihinde imzalanan Mondros Mütarekesi ile bitmiş, ancak ülkenin birçok yerinde başlayan işgaller Türkler açısından yeni bir mücadele safhasını teşkil etmiştir. Mustafa Kemal Paşa'nın 19 Mayıs 1919'da Samsun'a çıkışılla fiilî olarak başlayan Millî Mücadele ile vatanın düşman işgalinden kurtarılması ve milletin istiklalinin sağlanması amaçlanmıştır. Bu amaç doğrultusunda kongreler düzenlenmiş, Millî kuvvetler birleştirilmiş ve Türkiye Büyük Millet Meclisi'nin açılmasıyla mücadelenin tek elden yönetilmesi sağlanmıştır. Bu aşamada Heyet-i Temsiliye'nin teşkili ile milletin temsili meselesi kısmen ortadan kaldırılmış ve vatanın bütünlüğü için tüm imkânlar seferber edilmiştir. Mücadele sırasında kazanılan askerî başarıların siyasi başarılarla taçlandııılması ve vatanın sınırlarını belirleyen Misak-ı Millî́nin tanıtılması için yoğun çaba sarf edilmiştir. Doğu'da Ermenilere, Batı'da Yunan kuvvetlerine karşı kazanılan savaşlar ve TBMM hükümetinin başarılı diplomatik çabaları İtilaf Devletleri'ni 21 Şubat 1921'de Londra'da Sevr'in yumuşatılması için bir konferans toplamaya zorlamış, ancak konferans istenilen sonuca ulaşamadan dağılmıştır. Bu süreçte TBMM ve Misak-ı Millî́yi tanıyan ilk İtilaf Devleti, 20 Ekim 1921 'de imzalanan ve ön barış niteliğindeki Ankara İtilafnamesi ile Fransa olmuş, böylece düşman hattındaki çözülme derinleşerek devam etmiştir. Bu durum siyasi manada TBMM hükümetinin elini güçlendirirken, güney cephesindeki güçlerin batı cephesine nakledilmesi ve Fransa'dan alınan askerî ardımlar, düşman karşısında topyekûn savaş durumuna geçilmesini kolaylaştırmıştır. Bu çalışmayla, Mondros Mütarekesi'nden sonra Türk yurdunun işgali ile başlayan Millî Mücadele hareketinin diplomatik boyutu ve bu hareketin vatanı düşman işgalinden kurtarıp, artık Anadolu'da yeni bir devletin kurulduğunu tüm dünyaya ilan etmesine, yani ihtilalin tesciline kadar olan süreç ele alınacaktır.

Anahtar kelimeler: Mondros Mütarekesi, Millî Mücadele, Heyet-i Temsiliye, TBMM, Diplomasi

\section{ABSTRACT}

The First World War ended for the Ottoman Empire with the Armistice of Mudros signed on October 30,1918, but the occupations that started in many parts of Turkey constituted a new stage of struggle for the Turks. The aim of the National struggle, which had actually started with the arrival of Mustafa Kemal Pasha in 
Samsun May 19, 1919, was to save the country from the occupation of the enemy and to ensure the independence of the nation. For this purpose, congresses were organized and national forces were united, and the national struggle was managed from a central power with the establishment of the Grand National Assembly of Turkey. At this stage, with the formation of the Representative Committee, the issue of representation of the nation was partially eliminated and all opportunities for the integrity of the country were mobilized. Vigorous efforts were made to crown the military achievements gained during the struggle with political achievements and to promote the National Pact which defined the borders of the homeland. The battles won against the Armenians in the East and the Greek forces in the West and the successful diplomatic efforts of the government of the Grand National Assembly of Turkey forced the Allied Powers to convene a conference for the alleviation of Sevres in London on February 21, 1921, but the conference was disintegrated before reaching the desired result. In this process, the first Allied State to recognize the Grand National Assembly of Turkey and the National Pact was France with the Ankara Treaty signed on October 20,1921, which was a preliminary peace, and thus the dissolution of the enemy forces continued. While this situation strengthened the hand of the Grand National Assembly of Turkey government in political terms, the transfer of the forces from the southern front to the western front and the military aid received from France facilitated the transition to a total war situation against the enemy. In this study, the diplomatic dimension of the National Struggle movement which started with the occupation of the Turkish homeland after the Armistice of Mudros and the process of this movement starting from the liberation of the homeland from the enemy occupation to the declaration of the establishment of a new state in Anatolia to the whole world, namely the approval of the revolution, will be discussed. Keywords: Armistice of Mudros, National Struggle, Representative Committee, Grand National Assembly of Turkey, Diplomacy

\section{EXTENDED ABSTRACT}

The progress of the Ottoman Empire in Europe and the spread of Islam in this geography alarmed Christian European countries, and in time these states started to implement their plans which they called the "Oriental Question" and whose aim was to remove Turks from Europe and even Anatolia. The weaknesses that emerged in the administration of the Ottoman Empire weakened the state against the strengthened Europe. In the face of this situation, some European countries with imperialist goals agreed to share the lands of the Ottoman Empire and considered it as a right to intervene in the internal affairs of the state with pretexts such as political, military, economic impositions, and minority rights. The fact that these states were the victors of the First World War showed that the Ottoman lands would narrow and even Turks would not be granted the right to live in many regions. In accordance with the agreements reached by the Allied Powers, they immediately started to invade the lands of the Ottoman Empire at the end of the war and made many attempts in such a way that disregarded international law.

The Turkish nation, which remained unresponsive to the invasions, preferred to fight rather than live stateless and embarked on an important struggle against the occupation forces by establishing the National Forces. Meanwhile, with the support of the British, the invasion of Izmir by the Greek forces became the final straw and the occupation was protested all over the country. Mustafa Kemal Pasha, who was assigned to ensure public order around the Black Sea, started the National Struggle movement to spread the same understanding throughout the country. Mustafa Kemal Pasha, who managed to raise public awareness through congresses and meetings organized in various parts of Anatolia, became a threat for both Allied Powers and the Istanbul government. Mustafa Kemal Pasha challenged both parties by opposing the 
invasions and stating that the Istanbul government was not performing its duties in the face of these invasions.

The Allied Powers, who wanted to pass on the bill of the war to the defeated states and wanted to create legal ground by protecting their interests, first came together in Paris, but could not determine the provisions of the peace agreement to be signed by the Ottoman Empire. Later, the Allied Powers, which finalized the peace text with the London and San Remo conferences, were also able to make the Ottoman Empire sign the Sevres Agreement, which was the death sentence for the Turkish nation, to separate the Istanbul government from the National Struggle movement. However, the National Struggle movement, which started in Anatolia, declared to the world that it did not recognize the signed peace agreement or the Istanbul government. Their military success proved that the National Struggle and the Grand National Assembly of Turkey established in Ankara could not be ignored. The most important objective of the National Struggle movement, which succeeded in getting the text of the National Pact in the last Ottoman Parliament (Meclis-i Mebusan), opened in Istanbul, was to introduce this document to the whole world and it was once again declared that independence would not be compromised.

The significant achievements of the Grand National Assembly of Turkey and its regular army brought the Allies, especially France, to Ankara, and Ankara's government was forced to make peace by promising some changes to the unacceptable Sevres text. For this reason, the Allied Powers convened a conference in London and invited representatives of both the Istanbul government and the Ankara government. The Allied Powers, who wanted to take advantage of this situation, could not find what they had hoped for and realized that the unity between them had started to disintegrate. Mustafa Kemal Pasha noticed this issue and he immediately contacted the French counterparts in order to leave England alone against France. The Ankara Agreement signed between the government of the Grand National Assembly of Turkey and France was accepted as the first great diplomatic success of the National Struggle period and it was seen that the revolution, namely the liberation, was at the door. Realizing that they could not hold in Anatolia as a result of the Sakarya Pitched Battle and the Commander-in-Chief Battle, the Allied Powers had to come to the table for a ceasefire and then for peace. Finally the Turkish side, which had left the table as a defeated party five years ago, came to the table as the victorous state and the establishment of an independent Turkish state within the national borders was declared to the world.

As a result, the imperialist states that started with the Armistice of Mondros and tried to impose their ambitions on Turkish territory with the Treaty of Sevres failed in the face of the National Struggle movement initiated and executed by Mustafa Kemal Pasha and they had to accept the justified Turkish cause in the process from occupation to revolution. Although the new Turkish state, which had achieved a great deal of its national goals with the Treaty of Lausanne, had to deal with some border issues in the following years, it entered into a total renewal process in the judicial, financial, economic, legal and political fields. 


\section{Giriş}

Türklerin Avrupa'daki ilerleyişini 1683'te Viyana'da durdurmayı başaran Avrupa devletleri, bundan sonra Türklerin Avrupa'dan, hatta Anadolu'dan atılmaları gerektiğini düşünmeye başlamıştır. Bu düşünce zamanla büyük bir haçlı anlayışına dönüşmüş ve paylaşım planları, Rus Çarı Deli Pedro ile Avusturya İmparatoru II. Joseph zamanlarında başlayarak Sevr Antlaşması'na kadar devam etmiştir. İki ülke arasında başlatılan bu çalışmalara daha sonra Avrupa'nın diğer ülkeleri de katılmıştır. Avrupa devletlerinin paylaşıma dönük niyetleri 1815 ’te Viyana Kongresi'nde "şark meselesi”" tabiriyle ortaya çıkmıştır. Burada, Osmanlı topraklarında yaşayan gayrimüslim tebaanın himayesini anlatan "şark meselesi” tabiri, zamanla daha geniş bir anlam ifade etmeye başlamıştır. ${ }^{2}$ Rus Çarı I. Nikola’nın Ocak 1853 ’te Osmanlı Devleti için kullandığı "hasta adam” tabiri ise paylaşımın hızlandırılması, "şark meselesi”"nin nihayete erdirilmesi amacını taşımıştır. Dolayısıyla Osmanlı Devleti, 19. yüzyıldan itibaren birçok taraftan baskı altına alınmış, 1877-1878 Osmanlı-Rus Harbi, Trablusgarp ve Balkan savaşları sonucunda Avrupa'daki topraklarının tamamını kaybetmiştir.

20. yüzyılla birlikte başlayan bloklaşmalar, dünyayı büyük bir savaşa sürüklerken, kendi topraklarında cereyan edecek savaşta tarafsız kalması imkânsız olan Osmanlı Devleti'ni Almanya ile ittifaka sürüklemiştir. ${ }^{3}$ Böylece 4 yıl sürecek olan savaş, Avrupa devletleri açısından Osmanlı'nın tasfiyesi için bulunmaz bir firsatı ifade etmiştir. Savaş boyunca İtilaf bloğundaki ülkeler, kendi aralarında imzaladıkları gizli anlaşmalarla Osmanlı toprakları için paylaşım planları yapmış ve savaş sonunda da bu planları uygulamaya geçirmişlerdir. Aslında daha savaş başlamadan, 1911'de İngiliz diplomat Sir Mark Sykes tarafından yazılan mektupta kullanılan: “Türkiye diye bir şey artık var olmamalı. İzmir Yunanlıların olacaktır. Adana İtalyan, Güney Toroslar ve Kuzey Suriye Fransız, Filistin ve Mezopotamya İngiliz ve geri kalan, İstanbul dâhil Rusya (...)"4 ifadeleri, Osmanlı Devleti’nin topyekûn imhasına çalışıldığını göstermektedir.

İstanbul, Londra, Sykes-Picot, St. Jean de Maurienne gibi gizli anlaşmalarla paylaşılan Osmanlı toprakları üzerinde birçok millete bağımsız devletler vaat edilmiş, Rusya'nın savaştan çekilmesiyle de söz hakkı daha çok İngiltere ve Fransa'ya geçmiştir. Özellikle Ortadoğu coğrafyasının paylaşımı birçok kez bu iki devleti karşı karşıya getirirken, izlenen iki yüzlü politikalar Ortadoğu'da uzun yıllar sürecek olan istikrarsızlığa sebep olmuştur. Anadolu topraklarının paylaşımı ise Osmanlı Devleti açısından I. Dünya Savaşı’nın bittiğini ifade eden

1 Şark meselesi, “Avrupa büyük devletlerinin, Osmanlı Devleti’ni iktisadi, siyasi nüfuz ve hükmü altına almak veya sebepler ihdas ederek parçalamak ve Osmanlı idaresinde yaşayan çeşitli milletlerin bağımsızlıklarını temin etmek istemelerinden doğan tarihi meselelerin tümü” şeklinde tanımlanmıştır. Cevdet Küçük, "Şark Meselesi Hakkında Önemli Bir Vesika”, İ.̈̈. Edebiyat Fakültesi Tarih Dergisi 32 (1979), 607-638

2 Mustafa Turan, Siyasi ve Hukuki Açıdan Millî Mücadele (30 Ekim 1918-24 Temmuz 1923), 2. Bask1, (Ankara: Berikan Yayınevi, 2014), 13-14.

3 Ökkeş Narinç, “Birinci Dünya Savaşı'nda Bulgaristan ve Osmanlı Devleti Arasında Kurulan Güdümlü İttifak'ın Sona Ermesi”, Mondros Mütarekesi'nin 100. Yıll: I. Dünya Savaşı 'nın Sonu, Mütarekeler ve Barış Andlaşmaları içinde, (Ankara: Atatürk Araştırma Merkezi Yayınları, 2019), 1: 212.

4 İsmail Şahin, Cemile Şahin ve İsmail Şükür, “Ortadoğu'da Emperyalist Güçlerin Gizli Oyunu: Sykes-Picot Antlaşması”, The Journal of Academic Social Science Studies 38 (2015), 243. 
30 Ekim 1918 tarihli Mondros Mütarekesi ile başlamıştır. Mütareke’nin hemen sonrasında İtilaf Devletleri, Anadolu topraklarında işgallere başlamışlar ve emperyal amaçları doğrultusunda Türk milletini bağımsızlığından ederek boyunduruk altında yaşamaya mahkûm etmek istemişlerdir.

\section{Mondros Mütarekesi ve Osmanlı Devleti Topraklarının İşgali}

Osmanlı Devleti, Birinci Dünya Savaşı'nda mağlup olmuş ve 30 Ekim 1918 tarihinde imzaladığı Mondros Mütarekesi ile geleceğini belirleme hakkını İtilaf Devletleri'nin eline vermiştir. Amerikan Başkanı Woodrow Wilson'un yayımladığı ve Anadolu'da Türklerin çoğunlukta oldukları yerlerin Türklerin elinde kalacağı prensibine güvenerek imzalanan bu mütareke, İsmet (İnönü) Paşa'nın da belirttiği üzere, memleketin canını yakacak esaslı maddeler ihtiva etmiştir. ${ }^{5}$ Ali Fuat (Cebesoy) Paşa'nın “... galip devletler ahde vefa gösterebilecekler miydi? Yoksa bir kin ve intikam politikası mı güdeceklerdi?”' şeklinde yaklaştığı Mütareke'nin hemen ertesi günü başlayan işgaller, İtilaf Devletleri'nin asıl gayelerini ortaya koymuştur. Zira İngiliz temsilcisi Amiral Calthorpe ile Osmanlı Devleti temsilcisi Bahriye Nazırı Hüseyin Rauf (Orbay) Bey arasında imzalanan Mütarekenin yedinci maddesiyle İtilaf Devletleri emniyetlerini tehdit edecek bir durum karşısında herhangi bir stratejik noktayı işgal hakkına sahip olacaklardı. ${ }^{7}$

Aslında Ahmet İzzet Paşa hükümeti tarafından Mondros'a gitmek için görevlendirilen Rauf Bey başkanlığındaki heyete verilen 8 maddelik talimatta, Boğazların ticaret ve harp gemilerine açı olması, askerin terhisinin sağlanması, harp cephelerinin tecavüz edilmemesi ve millî gururu incitecek her çeşit isteğin reddedilmesi yer almıştır. ${ }^{8}$ Bunun yanında Padişah, halifeliğin ve Osmanoğulları soyunun haklarının korunması gibi bazı şartlar da eklenmesini istemiş, ancak Ahmet İzzet Paşa kendisinin de asıl maksadının bu olduğunu, böyle hususların mütareke konuşmaları içine dâhil edilmesinin uygun olmayacağını söyleyerek bu isteğe karşı çıkmıştır. 26 Ekim'de Mondros'a varan Türk heyeti, ertesi gün, daha önce kendilerine verilmemiş olan mütareke metnini dinleyerek müzakerelere başlamıştır. ${ }^{9} 28$ Ekim akşamı Babıali’ye gönderilen telgrafta mütareke şartlarının gayet ağır ve durumun son derece elim olduğu, İngiliz heyetinin müzakereyi kabul etmediği bildirilmiştir. 29 Ekim'de gelen cevabi telgrafta İstanbul Hükümeti, 11 maddelik bir tadilat taslağı hazırlamış ve bunun kabul ettirilmeye çalışılmasını istemiştir. 30 Ekim tarihli telgrafta ise doğudaki altı vilayet hakkındaki 24. maddenin gizli kalması, gerekirse buralara İtilaf denetçilerinin gönderilmesi ve elde edilecek tadilat neticesinde mütarekenin imzalanması bildirilmiştir. ${ }^{10}$ Nihayet 4 gün süren müzakereler sonucunda İngilizlerin

5 Sebahattin Selek, İsmet İnönü, Hatıralar (İstanbul: Bilgi Yayınevi, 1985), 1: 164.

6 Ali Fuat Cebesoy, Millî Mücadele Hatıralarl (İstanbul: Temel Yayını, 2000), 27.

7 Mondros Mütarekesi maddeleri için bkz. Türk İstiklal Harbi, Mondros Mütarekesi ve Tatbikat1, 3. Bask1, (Ankara: Genelkurmay Basımevi, 1999), 1: 42-49.; Kâzım Karabekir, İstiklâl Harbimiz, 2. Bask1, (İstanbul: Yapı Kredi Yayınları, 2008), 1: 2-5.; Yusuf Hikmet Bayur, Türk Inkılâbı Tarihi (Ankara: TTK Yayınları, 1983), 3/4: 742-746.; Fahri Belen, Türk Kurtuluş Savaşı (Ankara: Kültür ve Turizm Bakanlığı Yayınları, 1983), 11-13.; Sebahattin Selek, Anadolu İhtilali (İstanbul: Kastaş Yayınevi, 2010), 1: 44-48.; İsmail Soysal, Tarihçeleri ve Açıklamaları Ille Birlikte Türkiye ’nin Siyasal Andlaşmaları (1920-1945), (Ankara: TTK Yayınları, 1983), 1: 12-14.

8 Türk İstiklal Harbi, 1: 33-35.

9 Selâhattin Tansel, Mondros 'tan Mudanya'ya Kadar (Ankara: MEB Yayınları, 1977), 1: 22-23.

10 Türk İstiklal Harbi, 1: 38-40. 
hazırladığı mütareke metni küçük bazı değişikliklerle imzalanmıştır. Mütareke metni dışında Calthorpe, Rauf Bey’e bir mektup vererek mütarekenin birinci maddesine göre İstanbul ve Çanakkale boğazlarının işgalinde yalnızca İngiliz ve Fransız askerlerinin kullanılacağını garanti etmiştir. İşgal sonrası bölgede az sayıda da olsa Türk askerinin kalmasına müsaade edilmesini hükümetine tavsiye edeceğini belirten Calthorpe, hükümetine ayrıca ne İstanbul ne de İzmir'e Yunan askerinin girmesi gerektiğini sebepleriyle anlattığını da ifade etmiştir. ${ }^{11}$

Heyet Başkanı Rauf Bey, İstanbul'a dönüşünde gazetecilere verdiği beyanatta mütarekeyi imzaya giderken böylesine sevinçli döneceğini tahmin etmediğini ifade etmiş ve müzakereler sırasında İngilizlerin çok samimi hareket ettiklerini belirtmiştir. Mondros Mütarekesi ile devletin istiklali ve saltanatın hukukunun kurtarıldığını vurgulayan Rauf Bey, mütarekeyi “....yenen ile yenilen arasında yapılmış bir mütareke değil, savaş halinden çıkmak isteyen denk iki kuvvetin aralarındaki düşmanlığı durdurmaları hali gibi bir şeydir.” şeklinde yorumlamıştır. Rauf Bey ayrıca İngilizlerin Osmanlıları yaşatma fikrinde olduklarından bahisle, ne İstanbul'un ne de Adana'nın işgal edileceğini sözlerine eklemiştir. ${ }^{12}$ Rauf Bey'in bu 1lımlı tavrı Türkler arasında aşırı iyimser bir beklentiye sebep olurken Mondros heyeti kâtibi Ali Türkgeldi, İngilizlerin ağır mütareke şartlarını yumuşak tavırlarıyla telafi ettiğinden bahsetmiştir. ${ }^{13}$

Savaşın bitişi Sadrazam Ahmet İzzet Paşa’yı da memnun etmiş ve İngiliz temsilci Amiral Calthorpe'a bir teşekkür telgrafı göndermiştir. İzzet Paşa, Calthorpe'a delegelere gösterdiği ilgiden dolayı teşekkür ederek “Akdedilmiş bulunan mütarekenin İngiltere ile Türkiye arasında gerekli bir sulhun başlangıcı olacağına kani bulunmaktayım. İstikbalde iki memleket arasındaki dostane münasebetleri ve ahengi bir daha hiçbir hadisenin bozmaması için Cenâb-1 Hakk'a niyaz ederim." ${ }^{14}$ demiştir. Ayrıca Sadaret makamı, 2 Kasım'da bir genelge yayımlayarak mütareke şartlarının hafifliğinden söz etmiş ve ordulara gönderilen genelgeyle de asker kaçaklarına karşı kovalamanın durdurulmasını istemiştir. ${ }^{15}$ Sadrazam, çeşitli unsurlar arasındaki ahenkten, toprak kardeşliği ve huzurun devamı gibi konulardan bahsederken mütarekenin Türkler lehine olduğunu da eklemiştir. ${ }^{16}$ Gazetelere verdiği demeçte mütareke şartlarının Bulgaristan'a uygulanan şartlardan daha hafif olduğunu belirten Sadrazam, ülkenin işgalinin de talep edilmediğini sözlerine eklemiştir. ${ }^{17}$ Mütarekenin ağır şartlar taşıdığını düşünen Mustafa Kemal Paşa ise mütarekeyi, memleketin işgaline göz yumulması olarak değerlendirmiştir. ${ }^{18}$

11 Bayur, Türk İnklâbı Tarihi, 3/4: 751.

12 Türk İstiklal Harbi, 1: 50; Tansel, Mondros 'tan Mudanya'ya Kadar, 1: 26.

13 Ali Türkgeldi, Moudros (Mondros) ve Mudanya Mütarekelerinin Tarihi (Ankara: Türk Devrim Tarihi Enstitüsü Yayınlar1, 1948), 34.

14 Celal Bayar, Ben De Yazdım, Millî Mücadeleye Gidiş 1, (İstanbul: Sabah Kitaplar1, 1997), 61.; Türk İstiklal Harbi, 1: 51 .

15 Bayur, Türk Inkılâbı Tarihi, 3/4: 759.

16 İsmet İnönü, “Devlet Kurucusu Atatürk”, Belleten XXXIII/129 (1969), 1-19.

17 Salâhi R. Sonyel, Türk Kurtuluş Savaşı ve Dış Politika, 2. Baskı, (Ankara: TTK Yayınları, 1987), 1: 9.; Ahmet İzzet Paşa, Feryadım, yay. haz. Süheyl İzzet Furgaç-Yüksel Kanar, 2. Baskı, (İstanbul: Timaş Yayınları, 2017), 2: 33.

18 Bayur, Türk İnklâbı Tarihi, 3/4: 759. 
Hem İzzet Paşa'nın hem de Rauf Bey'in daha müzakereler devam ederken İngiliz siyasetinden yakınmaları, onların bir türlü müzakereye yanaşmadıkları, mütareke şartlarının İngilizler tarafından kendilerine dayatılmak istendiği gibi yorumları, sulhun sevinciyle unutulmuş ve kısa bir süre içerisinde de İtilaf Devletleri'nin Anadolu topraklarındaki asıl emelleri anlaşılmaya başlanmıştır. Daha önce onur kırıcı şartları kabul etmektense sonuna kadar savaşacaklarını söyleyen İzzet Paşa, mütarekeyi kabullenmekte bir sakınca görmemiştir.

Mütarekenin yürürlüğe girmesi, İtilaf Devletleri'ni harekete geçirmiş ve zaman kaybedilmeden işgaller başlatılmıştır. Birkaç gün içinde Musul ve İskenderun İngilizler; Dörtyol, Mersin, Tarsus ve Adana Fransızlar tarafından işgal edilmiştir. Mütareke masasına oturmadan önce Musul'u işgal etmek isteyen İngilizler, 18 Ekim'de saldırıya geçmişler, mütarekenin imzalandığı gün ise ileri harekâta devam etmişlerdir. 1 Kasım'da Hamam-1 Alil'e giren İngilizler, Musul'u işgal edeceklerini ve Türk kuvvetlerinin 5 mil daha kuzeye çekilmelerini istemişlerdir. ${ }^{19} \mathrm{Bu}$ durum karşısında 6. Ordu Komutanı Ali İhsan Paşa, 2. ve 5. Tümen komutanlıklarına işgali protesto etmeleri, ancak ateşle karşılık vermemelerini emretmiştir. Ertesi gün Ahmet İzzet Paşa, Ali İhsan Paşa'ya gönderdiği telgrafta mütareke şartlarında Musul'un boşaltılacağına dair bir maddenin olmadığını, savaşın hemen durması ve Musul'un Türk tarafinda kalması gerektiğini bildirmiştir. Ancak gerçekten büyük bir savaş hâli olursa savaşmadan Musul'un kuzeyine çekilmelerini de söylemiştir. İngiliz Kuvvetleri Komutanı General Marshall ise 3 Kasım'da mütarekenin 7. maddesine göre gerekli gördüğü stratejik noktaları işgale hakkı olduğunu ileri sürmüştür. İzzet Paşa buna karş1lık 7. maddede geçen "müttefiklerin güvenliklerini tehdit edecek vaziyet zuhurunda...” kaydını hatırlatıış ve İngilizlerin Musul'u almaya yetkilerinin olmadığını vurgulamıştır. ${ }^{20}$ Ancak 7 Kasım'da Osmanlı birliklerinin 15 Kasım öğleye kadar Musul'u boşaltmaları gerektiğini bildiren İngiliz ültimatomu karşısında şehrin boşaltılmasına başlanmış ve 8 Kasım günü Musul'a İngiliz bayrağı çekilmiştir. ${ }^{21}$

İtilaf kuvvetlerinin İskenderun'u işgal girişimleri Mütarekeden yalnızca 3 gün sonra bir Fransız torpidosunun bölgeye gelmesiyle başlamış ve 9 Kasım günü 15 kişilik bir İngiliz müfrezesi tarafından sonuçlandırılmıştır. 4 Kasım'da İskenderun Limanı ateşe tutulurken, Sadrazam Ahmet İzzet Paşa, Mustafa Kemal Paşa’ya gönderdiği bir telgrafta Fransızların şehre zorla girmek istemeleri durumunda karşılık verilmemesini ve bu durumun İngiliz Başkomutanlığ nezdinde protesto edilmesini istemiştir. Bu sırada İngilizler de Halep’teki kuvvetlerine erzak göndermek için İskenderun-Halep yolunu kullanmak istediklerini bildirmişler ve bu talep olumlu karşılık bulmuştur. Ahmet İzzet Paşa, İngilizlerin bu bölgeyi kullanmalarına neden müsaade ettiğini ise liman ve şehrin yine Osmanlı Devleti'nde kalacağı, onların sadece istifade edeceğini sebep göstererek açıklamıştır. Ancak İngiliz kuvvetlerinin asıl amaçları İskenderun ve Kilikya bölgesinin işgaline hazırlanmak olmuştur. Nitekim bu durumu fark eden Mustafa Kemal Paşa, 6 Kasım 1918 tarihli telgrafında İskenderun'a her ne sebeple olursa olsun asker

19 Turan, Siyasi ve Hukuki Açıdan Millî Mücadele, 31.

20 Bayur, Türk Inkılâbı Tarihi, 3/4: 760-761.

21 Turan, Siyasi ve Hukuki Açıdan Millî Mücadele, 31-32. 
çıkarmaya teşebbüs edecek olan İngilizlere ateşle karşılık verilmesi gerektiğini bildirmiştir. Ahmet İzzet Paşa ise böyle bir hareketin devletin izlediği siyasete uygun düşmeyeceğini ileri sürmüştür. Dolayısıyla liman ve şehir teslim edilmiş, aleyhte gösteri yapan Türklerin ise Fransız Komutan David Beauregard tarafından şehri terk etmeleri sağlanmıştır. ${ }^{22}$

Mütareke hükümlerine aykırı olarak gerçekleştirilen bir başka işgal girişimi de Adana'da yaşanmıştır. İngiliz baskısı karşısında tutunamayan Osmanlı Devleti, 22 Kasım' da bölgeden askerlerin çekilmesini kabul etmiş ve 26 Kasım'da da Adana vilayeti 2. Ordu birlikleri tarafindan Pozantı'ya kadar boşaltılmıştır. Bunun üzerine 17 Aralık'ta Mersin'e çıkarılan ve çoğunluğu Ermenilerden müteşekkil 1.500 kişilik Fransız birlikleri Tarsus, Adana ve Misis’i işgal etmiştir. İşgalden sonra bu kuvvetlerin 600'ü Adana'da bırakılmış, geri kalanı da İskenderun ve Ceyhan'a birer bölük, Toprakkale, Yenice ve Pozantı'ya birer takım, Islahiye, Tarsus ve Kelebek'e de birer müfreze şeklinde dağıtılmıştır. İşgaller sırasında, daha önce Mısır'da kurulan Lejyon Doryan isimli Ermeni Alayı da Fransız askeri üniformasıyla faaliyette bulunmuştur. Ayrıca Urfa, Antep, Maraş, Saimbeyli, Zeytin, Şar, Kozan, Osmaniye, Haruniye ve Mersin civarlarında yapılan muharebelerde de Ermeni milis kuvvetleri işgallere katılmıştır. Bu kuvvetler; Fransız üniforması giymiş askerler, emir komutaya bağlanmış Millî kuvvetler ve silahlı çeteler olarak üç gruba ayrılırken, bölgede toplam sayıları 10.150 civarında hesaplanmıştır. ${ }^{23}$

Ermeni birlikleri sadece Fransızların değil aynı zamanda İngiliz askerlerinin de yanında işgallere katılmış ve bu durum bölge halkının moralini olumsuz yönde etkileyen faktörlerin başında gelmiştir. Anadolu'nun önemli bir ticaret ve sanayi merkezi olan Antep 17 Aralık1918'de içinde Ermenilerin de bulunduğu İngiliz kuvvetleri tarafından işgal edilirken bunu Maraş'ın izleyeceği anlaşılmış ve 22 Şubat 1919'da da Maraş işgal edilmiştir. 24 Mart'ta Urfa'nın işgaliyle Güney Anadolu’nun önemli merkezleri İtilaf kuvvetlerini eline geçmiştir. ${ }^{24}$

İngilizlerin Kilis, Antep, Urfa ve Maraş'1 da içine alacak şekilde işgal bölgelerini genişletmeleri Fransa ile aralarında sorun yaşanmasına sebep olmuştur. ${ }^{25}$ Zira 16 Mayıs 1916 tarihli Sykes-Picot Anlaşması'na göre bu bölgeler Fransa'ya ait olacaktı. Anlaşmada ayrıca Suriye kıyıları, Çukurova (Kilikya), Sivas, Elazı̆̆, Maraş ve Mardin de Fransızlara verilirken, Halep-Şam-Musul üçgeninde de Fransız nüfuz bölgeleri oluşturulmuştur. Rusya’nın payına Trabzon, Erzurum, Van, Bitlis, Muş ve Siirt'in kuzeyinden İran sınırına kadar olan bölge düşerken, ${ }^{26}$ İngiltere'ye Basra'dan Bağdat'a kadar tüm Mezopotamya, Akka ve Hayfa limanları verilmiş ve neredeyse sınırsız bir nüfuz alanı tahsis edilmiştir. ${ }^{27} 1919$ yılının Ekim ayı sonuna kadar Urfa, Antep ve Maraş’ta işgallerine devam eden İngilizler, bu tarihten sonra, Sykes Picot Anlaşması hükümlerine göre buraları Fransızlara bırakmışlardır. ${ }^{28}$

22 Türk İstiklal Harbi, Güney Cephesi, (Ankara: Genelkurmay Basımevi, 2009), 4: 49-51.

23 Harp Tarihi Vesikaları Dergisi, $1 / 1$ (Ankara: Genelkurmay Basımevi, 1952), 49-52.

24 Harp Tarihi Vesikalarl Dergisi, 54-59.

25 Bige Yavuz, “1921 Tarihli Türk-Fransız Anlaşması”, Atatürk Araştırma Merkezi Dergisi VIII/23 (1992), $273-308$.

26 Türk Istiklal Harbi, Batı Cephesi, (Ankara: Genelkurmay Basımevi, 1994), 2/1: 1-2.

27 Yusuf Hikmet Bayur, Türkiye Devleti’nin Dış Siyasası (Ankara: TTK Yayınları, 1973), 11-12.

28 Türk Istiklal Harbi, 4: 59. 
Güney’deki işgaller bu şekilde devam ederken Batı Anadolu'yu ele geçirip Doğu Akdeniz havzasında hâkimiyet kurmayı planlayan İtalya da boş durmamıştır. Savaşa katılması karşılığında İngiltere ve Fransa tarafından 26 Nisan 1915'te Londra Anlaşması'yla Güneybatı Anadolu ve Akdeniz kıyıları İtalya'ya vaat edilmiştir. Üç devlet arasında 19-21 Nisan 1917'de imzalanan St. Jean de Mourinne Anlaşması'na göre ise Ayvalık Körfezi’nden başlayıp Balıkesir-Bursa hattından Afyon'a uzanan bölge de İtalyan nüfuz alanı olarak belirlenmiştir. ${ }^{29}$ Fakat 1915 yılında savaşa katılması karşılığında İzmir, Manisa, Denizli ve Muğla’yı da içine alan Aydın Vilayeti Yunanistan'a vaat edilmiştir. Söz konusu bu değişimin arkasında Doğu Akdeniz'de güçlenecek bir İtalya'nın İngiltere ve Fransa için önemli bir tehdit unsuru oluşturmasına karşı önlem alma amacı bulunmaktadır. ${ }^{30}$

Mondros Mütarekesi'nden hemen sonra Batı Anadolu'yu işgal etmek için hazırlıklara başlayan İtalya, 4 Ocak 1919'da Marmaris'e bir filo göndermiş, ancak İtilaf Yüksek Komiserliğinin devreye girmesiyle filo bir müddet bekletilmiştir. Asıl büyük sorun ise İzmir'de çıkmıştır. 7 Ocak'ta İzmir'e hem İtalya'dan hem de Yunanistan'dan birer siyasi temsilci gelerek kendi lehlerine propaganda yapmaya başlamışlardır. İzmir'in Yunanistan'a verileceğini anlayan İtalyanlar, 28 Mart 1919'da Antalya'yı işgal etmişlerdir. Önce Konya ve Burdur gibi yerleri işgal edeceği düşünülen İtalya, 11 Mayıs’ta Marmaris, Fethiye ve Bodrum'u işgal etmiştir. İleri harekâta devam eden İtalya, Güneybatı Anadolu'nun birçok yerini işgal ederken Edirne, Tekirdağ, Muratlı, Konya ve Eskişehir'e de çok miktarda asker sevk etmiştir. ${ }^{31}$

İtilaf Devletleri, Mondros Mütarekesi şartları ve uluslararası hukuk kurallarına aykırı hareket etmeye devam ederken Mütarekenin 11. maddesine göre Kars, Ardahan ve Batum'un boşaltılması talep edilmişstir. Bu talep karşısında 9. Ordu Komutanı Yakup Şevki Paşa'nın ağır hareket etmesi üzerine, İngiliz baskısı artmış ve Paşa görevden uzaklaştırılmıştır. Ardından da 17-18 Aralık 1918 tarihinde Batum'a gelen İngiliz kuvvetleri, 24 Aralık’ta Batum'u işgal etmiştir. Öte yandan 13 Kasım'da 22 İngiliz, 12 Fransız, 17 İtalyan ve 4 Yunan savaş gemisinin Dolmabahçe önünde demirlemesi büyük bir yıkıma sebep olmuştur. Zira İstanbul' da yaşayan Rumların Yunanistan lehine tezahüratı Türkler tarafındaki üzüntüyü bir kat daha artırmıştır. ${ }^{32}$ Devam eden günlerde Doğu Trakya, Karadeniz kıyıları ve Batı Anadolu'nun birçok yeri işgal edilmiştir.

İngiltere ve Fransa'nın Osmanlı topraklarındaki işgalleri devam ederken, Birinci Dünya Savaşı'nın mağlup devletleriyle imzalanacak barış antlaşmalarının tespiti, İtilaf Devletleri arasındaki siyasi, ekonomik anlaşmazlıkların giderilmesi ve sınır meseleleriyle ilgili pürüzlerin ortadan kaldırılması amacıyla başta İtilaf Devletleri olmak üzere toplam 32 devletin katılımıyla 18 Ocak 1919'da Paris’te bir konferans toplanmıştır. Bu konferansta ABD’nin isteği doğrultusunda Milletler Cemiyeti kurulmuş, ayrıca Almanya, Avusturya-

29 Türk Istiklal Harbi, 1: 210-211.

30 Turan, Siyasi ve Hukuki Açıdan Millî Mücadele, 34.

31 Türk Istiklal Harbi, 1: 211-221.

32 Tansel, Mondros 'tan Mudanya'ya Kadar, 1: 50-54. 
Macaristan İmparatorluğu ve Bulgaristan ile imzalanacak antlaşmaların taslakları hazırlanırken, Osmanlı Devleti ile imzalanacak antlaşma şartlarının daha sonra belirlenmesi yönünde bir karar alınmıştır. Böyle bir kararın alınmasında Rusya'nın savaştan çekilmesi ve daha önce Rusya'ya vaat edilen toprakların yeniden paylaşılması sorunu etkili olmuştur.

Osmanlı topraklarının eşit bir şekilde paylaşılması düşüncesi, Paris’te birtakım değişiklerin olacağını göstermiştir. Bu anlamda 30 Ocak’ta ABD Başkanı Wilson’un önerisi üzerine bir prensip kararı alınmış ve Suriye, Mezopotamya (Irak), Filistin ve Arabistan topraklarının Osmanlı Devleti'nden tamamen koparılması yönünde fikir birliğine varılmıştır. ${ }^{33}$ Konferansta savaş sırasında imzalanan gizli anlaşmaların aynen uygulanması kararı da alınmıştır. Böylece hem İtalya hem de Yunanistan daha önce imzaladıkları gizli anlaşmalara dayanarak toprak paylaşımı noktasında ısrarcı davranmışlardır.

Konferansta Yunan temsilcisi Elefterios Venizelos, Kıbrıs, Oniki Ada ve tüm Ege adaları, Epir, Batı Trakya, Marmara Denizi ile birlikte, İkinci Balkan Savaşı'nda Bulgaristan'a bırakılan toprakların büyük kısmının Yunanistan'a verilmesini talep etmiştir. Şerif Hüseyin'in oğlu Faysal kendisine krallık verilmesini isterken, 26 Şubat'ta Ermeni temsilcileri Bogos Nubar Paşa ile Avetis Aharoniyan, Trabzon'un batısından Mersin Limanı'na uzanan hat boyunca bir Ermenistan devleti kurulması talebinde bulunmuşlardır. ${ }^{34}$ Siyonist temsilciler ise sınırları kuzeyde (Lübnan) Sidon, doğuda Hicaz demiryolu yakınından geçip güneyde Akabe körfezinde biten ve sınırları batıda Akdeniz olarak belirlenen bir Yahudi devleti kurulmasını talep etmişlerdir. Günümüzde bu sınırlar, Filistin'in tamamı, Güney Lübnan, Suriye, Ürdün ve Birleşik Arap Emirliği'ni kapsamaktadır. ${ }^{35}$

Paris'te sunulan taleplerin bazıları karşılık bulurken büyük bir kısmı ertelenmiştir. Osmanlı Devleti ile yapılacak barış antlaşmasının şartları ise Şubat 1920'de Londra ve Nisan'da San Remo konferansları neticesinde nihayete erdirilmiştir. San Remo'da daha çok Ermeni devletinin kuruluşu ${ }^{36}$ ve Filistin'in İngiliz mandasına devri konuları tartışılmıştır. Ayrıca Irak ve Filistin'de İngiliz mandası, Suriye'de ise Fransız mandası kurulması, İngiliz himayesinde bir Kürdistan devleti kurulup Doğu Anadolu'nun Ermenilere verilmesi planlanmıştır.

Osmanlı toprakları üzerindeki Yunan iddialarının yanlış olduğu kanıtlanmasına rağmen, 7 Mart'ta Yunanistan'ın Trakya'daki talepleri kabul edilmiş, Oniki Ada ve Batı Anadolu'daki isteklerine ise İtalya karşı çıkmıştır. 24 Nisan'da konferanstan çekilme kararı alan İtalya işgal planlarını uygulamaya koyarken, ${ }^{37} 15$ Mayıs’ta bir İngiliz savaş gemisinin himayesinde birkaç

33 Bige Yavuz, Kurtuluş Savaşı Döneminde Türk-Fransız İlişkileri (Ankara: TTK Yayınları, 1994), 9.

34 İsmail Köse, "Paris Barıș Konferansı Tutanakları ve Başkan Woodrow Wilson’un Türk Algısı", History Studies 6/3 (2014), 217-238.; Konu ile ilgili ayrıntılı bilgi için bkz. Kamuran Gürün, Ermeni Dosyası (Ankara: TTK Yayınları, 1983); Ayrıca bkz. Bayram Kodaman, Ermeni Macerası (Isparta: Süleyman Demirel Üniversitesi Yayınlar1, 2001).

35 Ataöv, Türkkaya, "Filistin Sorununun Ardındaki Gerçek: İsrail'in Kuruluşuna Kadar", Ankara Üniversitesi SBF Dergisi 25/3 (1970), 29-66.

36 Konu hakkında ayrıntılı bilgi için bkz. Mehmet Sait Dilek ve Evren Küçük, “San Remo Konferansı'nda İngiltere'nin Ermeni Politikas1 (18-26 Nisan 1920)", Turkish Studies 7/3 (2012), 959-971.

37 Yavuz, Kurtuluş Savaşı Döneminde Türk-Fransız İlişkileri, 10. 
Yunan gemisi İzmir limanına girmiş ve hızlı bir şekilde önemli yerlerin işgaline girişilmiştir. İşgal haberini alan İstanbul hükümeti, hazırladığı notayı Amiral Webb'e sunmuş ve Paris Barış Konferansı'nda İzmir'in Müttefikler tarafından işgal edileceği kararı alındığı hâlde, Yunan askerinin şehri işgali için bir sebep bulunmadığ bildirilmiştir. $^{38}$

\section{Millî Mücadele Hareketi ve Heyet-i Temsiliye Diplomasisi}

İzmir'in Yunan askeri tarafından işgali tüm ülkede derin bir üzüntüyle karşılanmış ve bu işgal İzmir'e kara bir bulutun çöktüğü şeklinde yorumlanmıştır. İşgali kabul edemeyen İstanbul hükümeti de derhal bu işgali protesto etmiştir. Harbiye Nazır Vekili Cevat (Çobanlı) Paşa ise bütün birliklere gönderilmek üzere kaleme aldığı yazıda Türk birliklerinin yerlerini terk etmemesi, bir oldubittiye firsat vermemek için toplu hâlde silah başında beklenmesini istemiştir. ${ }^{39}$ İşgalin ağırlığı karşısında 57. Tümen Komutanı Albay Şefik, 23 Mayıs 1919 tarihinde Harbiye Nezareti'ne sunduğu raporunda ilk kez "Kuvayı Millîye” fikrinden bahsetmekte, raporun altına "son fıkra gayet mühimdir, istical lazımdır." kaydını düşen Cevat Paşa'nın da aynı fikirde olduğu anlaşılmaktadır. ${ }^{40}$

Yunan kuvvetleri İzmir'in işgalinden sonra ileri harekâtlarına devam ederken Büyük Menderes Vadisi'nin ele geçirilmesi için de birtakım girişimlerde bulunulmuştur. Buna göre Venizelos, 19 Mayıs’ta Paris Barış Konferansı Heyeti'ne başvurarak kuzeyde Ayvalık, güneyde ise Aydın'a kadar uzanan toprakların Yunan kuvvetleri tarafından işgal edilmesi için izin istemiştir. Müttefikler Konseyi, Yunan birliklerinin Selçuk’un güneyine geçmemeleri şartıyla Büyük Menderes Vadisi'nin işgaline razı olmuşlardır. Böylece 27 Mayıs sabahı Yunan kuvvetleri hiçbir mukavemetle karşılaşmadan Aydın'ı işgal etmiştir. İşgaller karşısında Ödemiş Kaymakamının 30 Mayıs 1919 tarihinde İzmir Valisine çektiği telgrafta geçen “... İzmir'e Yunan ayağının bastırılmasıyla cinayet işlendiği ve insanlık âleminin ateş ve kan içinde bırakıldığı..." düşüncesi, Türk halkının bu duruma sessiz kalamayacağı ve topyekûn bir savaşa girişeceğini göstermiştir. ${ }^{41}$ Zaten Miralay Kazım (Özalp) Bey’in de belirttiği gibi işgallerin hemen ardından Reddi İlhak Cemiyetinin teşkili ve Millî kuvvetlerin hazırlıkları hakkında alınan memnuniyet verici haberler, Millî Mücadelenin lider kadrosunu son derece mutlu etmiştir. ${ }^{42}$

Aynı tarihlerde Karadeniz bölgesinde Pontus Rum çetelerinin Müslüman ahaliye saldırıları çoğalmış, ancak işgal güçleri bu saldırıların sebebini Türklerin Hristiyanlara saldırılarında görmüşlerdir. İngilizler asayişin sağlanamaması durumunda bölgeyi işgal edeceklerini bir nota ile bildirirken, Sadrazam Damat Ferit Paşa, önce İngiliz siyasi temsilcisi ardında da Dâhiliye Nazırı Mehmet Ali Bey'le durumu müzakere etmiştir. Mehmet Ali Bey’in asayişi sağlamak üzere bölgeye geniş yetkilerle Mustafa Kemal Paşa'nın gönderilmesini tavsiye etmesi üzerine,

38 Tansel, Mondros 'tan Mudanya 'ya Kadar, 1: 189-200.

39 Kâzım Özalp, Millî Mücadele, 4. Baskı, (Ankara: TTK Yayınları, 1998), 1: 10.

40 Türk İstiklal Harbi, 2/1: 62.

41 Türk Istiklal Harbi, 2/1: 68-73.

42 Özalp, Millî Mücadele, 1: 13. 
Damat Ferit Paşa da bunun yerinde bir karar olacağını düşünmüş ve 30 Nisan 1919 tarihinde hazırlanan irade-i seniyye ile Mustafa Kemal Paşa 9. Ordu Müfettişliğine atanmıştır. ${ }^{43} \mathrm{Bu}$ suretle Mustafa Kemal Paşa, Trabzon, Erzurum, Sivas, Van vilayetleriyle birlikte Erzincan ve Canik müstakil livalarına gerekli tüm emirleri verebilecek ayrıca Bitlis, Ma'muretü'l-aziz, Ankara, Kastamonu vilayetleri ile kolordu kumandanları da onun görevi sırasındaki tüm müracaatlarını dikkate alacaklardı. Daha sonra Maraş ve Kayseri'nin de bu geniş sorumluluk alanına dâhil edildiği bildirilmiştir. ${ }^{44}$ Böylece Mustafa Kemal Paşa rahat hareket edebileceği bir firsat yakalamış ve vatanın kurtuluşunun Millî kuvvetlerin birleştirilmesinden geçtiğini tüm halka anlatabilmek için 16 Mayıs 1919'da İstanbul'dan Samsun'a hareket etmiştir.

19 Mayıs’ta Samsun'a ulaşan Mustafa Kemal Paşa, ülkenin genel durumunu değerlendirmiş ve "Millî hâkimiyete dayanan, kayıtsız şartsız, bağımsız yeni bir Türk devleti kurma"45 kararını hayata geçirmek için çalışmalarına başlamıştır. Türk milletinin haysiyet, gurur ve kabiliyetinin çok yüksek olduğunu vurgulayan Mustafa Kemal Paşa, böyle bir milletin esir yaşamaktansa yok olmasının daha iyi olacağını belirtmiş, ${ }^{46}$ bütün milleti ve orduyu ayaklandırmanın gerekliliği üzerinde durmuştur. Bölgede kolordu komutanlarıyla yaptığı yazışmalar sayesinde Türk askerî gücünü yakından tanıma firsatı bulan Mustafa Kemal Paşa, diğer taraftan da sivil idareciler vasıtasıyla halkın işgallere karşı bilinçlenmesinin sağlanması ve protesto mitingleri düzenlenmesini organize etmiştir. Ancak bu eylemler, 8 Haziran'da Mustafa Kemal Paşa'nın Harbiye Nezareti kanalıyla İstanbul'a geri çağrılmasına sebep olmuştur. ${ }^{47}$ Mustafa Kemal Paşa ise 21-22 Haziran 1919 tarihlerinde yayımlanan Amasya Genelgesi ile ilk kez İstanbul hükümetine meydan okumuştur. Genelgede ülkenin bütünlüğü ve bağımsızlığının tehlikede olduğu, bu durumdan ancak milletin azim ve kararıyla çıkılabileceği vurgulanırken İstanbul hükümetinin üzerine düşen sorumluluğu yerine getirmediği ifade edilmiştir. ${ }^{48}$ Mustafa Kemal Paşa, ayrıca İstanbul'da Abdurrahman Şeref Bey, Ahmet İzzet Paşa, Halide Edip, Kara Vasıf Bey, Ahmed Rıza Bey gibi bazı kimselere gönderdiği mektubunda sadece miting ve gösterilerin büyük amaçları gerçekleştirmek için yeterli olmadığını ve artık İstanbul'un Anadolu'ya hâkim değil, bağlı olmak mecburiyetinde bulunduğunu ifade etmiştir. Dâhiliye Nazırı Ali Kemal Bey ise bir genelge yayımlamış ve Mustafa Kemal Paşa'nın görevden alınmış olduğunu, kendisi ile hiçbir resmî işleme girilmemesi gerektiğini ve hükümet işleri ile ilgili hiçbir isteğinin yerine getirilmemesini bildirmiştir. ${ }^{49}$ İşgal güçleri Başkomutanı General Milne ise 30 Haziran’da Mustafa Kemal Paşa'nın görevden alınması talebini yinelemiş ve Sivas’ta Mustafa Kemal

43 Harp Tarihi Vesikaları Dergisi, Sayı 1, Vesika no: 1.

44 Harp Tarihi Vesikaları Dergisi, Say1 1, Vesika no: 13.; Tansel, Mondros 'tan Mudanya'ya Kadar, 1: 226-230.; Ayrıca bkz: Ökkeş Narinç, “1919-1920 Yıllarında Müfettişlik Müessesesi”, Asia Minor Studies Dergisi 1/1 (2013), 77-93.

45 Atatürk, Nutuk, 1919-1927, yay. haz. Zeynep Korkmaz, (Ankara: Atatürk Araştırma Merkezi Yayınları, 2006), 1-9.

46 Atatürk, Nutuk, 10.

47 Harp Tarihi Vesikaları Dergisi, Sayı 1, Vesika no: 19.

48 Yavuz, Kurtuluş Savaşı Döneminde Türk-Fransız İlişkileri, 23-24.

49 Atatürk, Nutuk, 24-25. 
Paşa ile Konya'da Cemal Paşa'yı iki kışkırtıcı olarak değerlendirmiştir. Milne ayrıca Millî Mücadele hareketinden duyduğu rahatsızlığg dile getirerek, bu akımın daha da güçlenmeden önlenmesi gerektiğini vurgulamıştır. ${ }^{50}$

Amasya Genelgesi hazırlıkları sürerken 28 Mayıs 1919 tarihinde Ermenistan Cumhuriyeti ilan edilmiş ve kurulan hükümet, dünya üzerindeki tüm Ermenileri temsil eden bir yetkiyle donatılmıştır. Öte yandan 11 Haziran 1919'da Ermeni kuvvetlerinin Türk hududunda yığınaklarını artırdığı ve Müslüman ahaliye saldırılara giriştiği haberleri gelmiş ve 15. Kolordu tedbir almak için görevlendirilmiştir. ${ }^{51}$ Bunun üzerine Doğu İlleri Müdafaa-i Hukuk Cemiyeti'nin Doğu Şubeleri ile Trabzon Muhafaza-i Hukuk Cemiyeti, İngilizler tarafından Ermenilere teslim edilen Kars'tan sonra Erzurum'un da bir Ermeni saldırısına uğramasının ve Trabzon civarında devlet kurma hayalinde olan Pontusçuların önüne geçmek için Erzurum'da bir kongre toplamaya karar vermişlerdir. ${ }^{52} 17$ Haziran'da ilk kongresini yapan Erzurum Müdafaa-i Hukuk Cemiyeti, herhangi bir Ermeni saldırısı karşısında sonuna kadar savaşmak ve Osmanlı camiasından ayrılmamak için her türlü fedakârlığı göze almak gibi kararlar almıştır. ${ }^{53}$

Erzurum'daki asıl önemli kongre 23 Temmuz-7 Ağustos tarihleri arasında yapılmış, ${ }^{54}$ bu kongre vatanın bütünlüğü ve milletin bağımsızlığı prensibini esas aldığı için bölgesel olmaktan çok, ulusal bir nitelik taşımıştır. Ayrıca bu kongreyle Millî direniş teşkilatları "Şarkî Anadolu Müdafaa-i Hukuk Cemiyeti” adıyla birleştirilmiştir. Burada alınan en önemli kararlardan birisi de Doğu illerini temsil etmek ve kararları uygulamak için oluşturulan Heyet-i Temsiliye'nin ${ }^{55}$ kuruluşudur. ${ }^{56}$ Kongre Beyannamesinin 3. maddesinde belirtilen vatanı koruma ve istiklali temin etme gayesi için geçici bir hükümetin kurulacağı ve bu hükümet üyelerini kongre heyetinin seçeceği yaklaşımı, kuvvetler birliği prensibine dayanırken bundan sonraki uygulamalar Heyet-i Temsiliye'nin hükümet vazifesini bizzat kendisinin üstleneceğini göstermiştir. Bu durum Türkiye Büyük Millet Meclisi’nin açılışına kadar devam etmiş, siyasi ve diplomatik faaliyetler Heyet vasitasıyla yürütülmüştür.

Erzurum'dan sonra 4-11 Eylül 1919 tarihleri arasında “... Anayasadaki açıklığa rağmen, Âyan ve Mebusan meclislerini hâlâ toplamamış bir idareyi gören bu zavallı millet, meşru hakkına dayanarak ve hiçbir parti hırs ve özel görüşüne uymadan vatanın çökmesine engel olacak son

50 Salâhi R. Sonyel, Mustafa Kemal (Atatürk) ve Kurtuluş Savaşı (Ankara: TTK Yayınları, 2008), 1: $286-287$.

51 Türk İstiklal Harbi, Doğu Cephesi (1919-1921), (Ankara: Genelkurmay Basımevi, 1995), 3: 21.

52 Yavuz, Kurtuluş Savaşı Döneminde Türk-Fransız İlişkileri, 25.

53 Türk Istiklal Harbi, 3: 26.

54 Erzurum Kongresi hakkında ve alınan kararlar için bkz. Bekir Sıtkı Baykal, Erzurum Kongresi İle İlgili Belgeler (Ankara: Türk İnkılâp Tarihi Enstitüsü Yayınları, 1969), 23 vd.

55 Doğu illerini temsil eden Heyet-i Temsiliye üyeleri şunlardır: Mustafa Kemal (Eski 3'üncü Ordu Müfettişi), Rauf Bey (Eski Bahriye Nazırı), Raif Efendi (Eski Erzurum Milletvekili), İzzet Bey (Eski Trabzon Milletvekili), Servet Bey (Eski Trabzon Milletvekili), Şeyh Fevzi Efendi (Erzincan’da Nakşî Şeyhi), Bekir Sami Bey (Eski Beyrut Valisi), Sadullah Efendi (Eski Bitlis Milletvekili), Hacı Musa Bey (Mutki Aşiret Beyi).

56 Mustafa Kemal Paşa, Erzurum Kongresi kararlarını 7 maddede özetlerken, Kazım Karabekir, Şarki Anadolu Vilâyâtının Erzurum Kongresi Beyannamesi adıyla kongre kararlarını 10 madde halinde aktarmıştır. Karabekir, Istiklâl Harbimiz, 1: 115-116. 
tedbirleri almak üzere..." ${ }^{57}$ Sivas’ta gerçekleştirilen kongre, ${ }^{58}$ ülkedeki tüm Müdafaa-i Hukuk Cemiyetlerini “Anadolu ve Rumeli Müdafaa-i Hukuk Cemiyeti” adı altında birleştirerek, mücadelenin tek elden yürütülmesini kolaylaştırmıştır. Erzurum'da kurulan Heyet-i Temsiliye ise Sivas'ta tüm yurdu temsil edecek şekilde yeniden organize edilmiş ve Ali Fuat Paşa'yı Batı Anadolu Umum Kuva-yı Millîye Kumandanlığına atayarak ilk icraatını da gerçekleştirmiştir. Heyet-i Temsiliye tarafından alınan bu kararlar bazı komutan ve fikir adamlarını telaşlandırmış ve bu kimselerde İstanbul'dan bağımsız kurulacak bir hükümetin zayıf olacağı kanaatini uyandırmıştır. ${ }^{59}$ Millî Kongre adına gerektiğinde geçici hükümeti teşkil yetkisine sahip yarı yasama, yarı yürütme gücünü elinde bulunduran bir teşekkül olarak ifade edilen Heyet-i Temsiliye, bundan sonraki mücadelenin tek hâkimi, Mustafa Kemal Paşa da tek yürütücüsü olacak, ${ }^{60}$ ancak İstanbul hükümeti, Heyet-i Temsiliye'nin bir çete olduğunu ilan etmekten geri durmayacaktır.

Sivas Kongresi, Millî mücadelede kurulan başsız teşkilata ve karargâhı olmayan silahlı mücadeleye kılavuzluk etmiş, emir ve komutayı ele almak bakımından büyük önem taşımıştır. ${ }^{61}$ Bu bağlamda Sivas'ta 11 Eylül günü Damat Ferit Paşa hükümetine duyulan güvensizlik sebebiyle İstanbul ile her türlü münasebeti kesme kararı alınmış ve Damat Ferit Paşa’ya gönderilen bir telgrafla son ihtar yapılmıştır. ${ }^{62}$ Heyet, 14 Eylül'de de Padişaha bir telgraf göndererek Damat Ferit Paşa hükümetini Aydın faciasını önleyememek, Paris Barış Konferansı'ndan kovulmak, Millî meclis için seçim yaptırmamak ve Millî teşkilatı dağıtmaya çalışmakla suçlamıştır. ${ }^{63}$ Damat Ferit Paşa bunun üzerine Padişahı da yanına alarak bir beyanname hazırlatmıştır. Millî Mücadele karşıtı olan bu beyannamede işgal haberlerinin rivayetler üzerine kurulu olduğu belirtilmiş ve girişilecek hareketlerin makul olması gerektiği vurgulanmıştır. ${ }^{64}$ Damat Ferit Paşa, her ne kadar bu beyannameyi tüm il ve ilçelere göndermek istemişse de Millî Mücadele taraftarlarının aldığı önlemler sayesinde başarısız olmuştur. Heyet-i Temsiliye de

57 Belen, Türk Kurtuluş Savaşı, 111.

58 Sivas Kongresi hakkında ve alınan kararlar için bkz. Uluğ İğdemir, Sivas Kongresi Tutanakları (Ankara: TTK Yayınları, 1986), $113 \mathrm{vd.}$

59 Ali Fuat Cebesoy, "Mustafa Kemal-Millî Lider", Belleten XX/80 (1956), 549-555.

60 Turan, Siyasi ve Hukuki Açıdan Millî Mücadele, 51.

61 Türk İstiklal Harbi, Batı Cephesi, 3. Baskı, (Ankara: Genelkurmay Basımevi, 1999), 2/2: 12.

62 11-12 Eylül gecesi Damat Ferit Paşa’ya gönderilen telgraf şu şekildedir: "Vatan, millet ve Padişaha hainliğiniz açıkça bizim tarafımızdan bilinmektedir. Milletin, Padişahımızın başka hiç birinize emniyeti kalmamıştır. Hepinizin meşru olmayan hareketlerinin sonucundan korkarak millet ile Padişah arasındaki bağlantıya engel oluyorsunuz. Bu haliniz, daha bir saat devam ederse millet artık kendisini, her türlü harekât ve icraatında serbest görecektir. Bütün vatanın sizlerle olan irtibatı kesilecek, burada bulunan yabancı subaylar vasıtasıyla İtilaf Devletleri temsilcilerine duyurulacaktır." Türk Istiklal Harbi, 2/2: 20-21.; Selek, Anadolu Ihtilali, 1: 306.

63 Telgraf şu şekilde sona ermiştir: "Bu vaziyeti nazar-1 itibara alan heyet-i memlükanemiz, vatanı kurtaracak son çare olmak üzere hiçbir siyasi partiye mensup olmayacak ve millî iradeyi tamamıyla izhar ederek, millete istinat edecek bir vekiller heyetinin işbaşına getirilmesini istemek ve niyaz ile böyle bir kabine teşekkül etmediği takdirde milletin teşebbüsat ve icraat-1 zaruriyesini duyurmaya imkân olmayacağını arz ederiz. Her ahvalde emr-i ferman sevgili Padişahımız, efendimiz hazretlerinindir.” Selek, Anadolu İhtilali, 1: 310.

64 Selek, Anadolu İhtilali, 1: 311-312.; Selahattin Tansel, Mondros 'tan Mudanya 'ya Kadar, (Ankara: MEB Yayınlar1, 1978), 2: 134-136. 
bu beyannameye karşılık Padişah'a gönderdiği başka bir telgrafta, halkı birbirine düşüren bu kabinenin iktidarda kalmasının büyük felaketlere yol açacağını bildirmiştir. Nihayet Damat Ferit Paşa kabinesi 2 Ekim 1919 tarihinde görevden çekilmek zorunda kalmış ve yerine daha 1lımlı bir siyaset güden Ali Rıza Paşa hükümeti kurulmuştur. ${ }^{65}$

\subsection{Amasya Görüşmeleri}

İstanbul'da yeni kurulan hükümetle temas arayan Heyet-i Temsiliye, 3 Ekim günü Meclis-i Vükelâ' da kendileriyle görüşüleceği yönünde söz verildiğini öğrenmiştir. Bunun üzerine Mustafa Kemal Paşa bir genelgeyle yeni kabinenin Erzurum ve Sivas kongrelerinde alınan kararlara saygılı olması durumunda Kuva-yı Millîye'nin kendilerine yardımcı olacağını bildirmiştir. Genelgede Millî Meclis'in toplanmasına kadar yeni hükümetin milletin kaderi ile ilgili herhangi bir taahhüde girmeyeceğini de vurgulayan Mustafa Kemal Paşa, barış konferansına tayin edilecek temsilcilerin de milletin güvenini kazanmış, bilgili ve yetenekli kişilerden seçilmesi gerektiğini ifade etmiştir. ${ }^{66}$ İki taraf arasındaki yazışmalarda Millî Mücadele’ye yardım ettikleri için azledilen memurların görevlerine iadesi, bu sebeple açılan soruşturmaların durdurulması, bu harekete ihanet eden valilerin devlet hizmetinde kullanılmaması, önemli askerî makamların ehil ellere bırakılması gibi talepler dile getirilmiştir. Erkân-1 Harbiye-i Umumiye Riyâseti'ne Cevat Paşa ya da Fevzi Paşa'nın, Harbiye Nezareti Müsteşarlığı'na da Albay İsmet Bey'in tayin olunmaları istenirken, hükümetin yayımladığı bildirilerin yayınlanmadan önce görülmesi de talep edilmiştir. ${ }^{67}$ Böylece Hükümet, Heyet-i Temsiliye ile daha yakından temas kurulmasını lüzumlu görerek, Bahriye Nazırı Salih Paşa’yı Amasya’ya göndermiş ve 20-22 Ekim 1919 tarihleri arasında yapılan müzakereler sonucunda bir anlaşmaya varılmıştır. ${ }^{68}$ Buna göre Millî teşkilat ve hükümet arasında bir anlaşmazlık kalmadığı, vatan topraklarının bütünlüğü ve istiklalin muhafazasının esas olduğu, Müslüman olmayan unsurlara imtiyaz verilmeyeceği, milletvekili seçimlerinin serbestçe yapılacağı, Sivas Kongresi kararlarının Meclis-i Mebusan'da kabul olunacağı gibi kararlar alınmıştır. ${ }^{69} \mathrm{Bu}$ sıralarda Anadolu'ya gelen ve yabancı gözlemcilerden oluşan bir heyete Millî Mücadele'nin en iyi şekilde tanıtılması için kolordu ve firka kumandanlıklarına Heyet-i Temsiliye adına önemli bir de telgraf gönderilmiştir. ${ }^{70}$

Amasya görüşmelerinden sonra Mustafa Kemal Paşa, Müdafaa-i Hukuk Cemiyetlerinin merkeze bağlanması, cephelerle meşgul olmak ve seçim hazırlıklarını yakından takip etmek üzere, Heyet-i Temsiliye'nin diğer üyeleriyle yaptı̆̆ı müzakereler sonucunda Ankara'ya geçmeye karar vermiştir. Yapılan hazırlıklar sonucunda Heyet, 18 Aralık 1919 tarihinde

65 Sonyel, Mustafa Kemal (Atatürk) ve Kurtuluş Savaşı, 1: 143-148.

66 Atatürk, Nutuk, 134.

67 İstanbul hükümeti ile Heyet-i Temsiliye arasında geçen yazışmalar için bkz. Selek, Anadolu İhtilali, 1: 315-323.

68 Amasya görüşmelerinin detayı için bkz. Atatürk, Nutuk, 166-171.

69 Tansel, Mondros 'tan Mudanya'ya Kadar, 2: 145-146.; Türk İstiklal Harbi, 2/2: 78.

70 100. Yılında 1919 Arşivimizden Belgeler (Ankara: Dışişleri Bakanlığı Diplomatik Arşiv Dairesi Başkanlığı, 2019), 10-11. 
Sivas'tan ayrılmış ve 27 Aralık'ta Ankara'ya ulaşmıştır. ${ }^{71}$ Heyet, Ankara'ya gelişini ve artık Heyet-i Temsiliye'nin merkezinin Ankara olduğunu bir tebliğ ile duyurmuştur. ${ }^{72} \mathrm{Bu}$ arada 15. Kolordu Komutanı Kazım Karabekir Paşa, 3 Ekim tarihli telgrafında doğu illerinin Kuva-yı Millîyesi olarak tanımladığı Heyet-i Temsiliye'nin bölgeden uzaklaşmasını, buradaki illerin teşkilatsız kalacağı gerekçesiyle yerinde bulmadığını beyan etmiştir. O’na göre Heyet'in 3 ay daha Sivas'ta kalması bu uyarının tesiriyle olmuştur. ${ }^{73}$

\subsection{Misak-ı Millı̂’nin Hazırlanması}

Mustafa Kemal Paşa, Ankara’ya gelişinin hemen ertesi günü çalışmalarına başlamış ve şehrin ileri gelenlerini bir araya toplayarak nasıl bir yol izlenmesi gerektiğini anlatmıştır. Burada Wilson ilkelerinin 12. maddesinin Türkiye için uygulanabilir olduğunu belirten Paşa, Mondros Mütarekesi'nden sonra bu ilkelerin İtilaf Devletleri'nce nasıl çiğnendiğine değinmiştir. O’na göre Mondros'un imzalandığı andaki sınırlar tüm devletler tarafından benimsenmeliydi. Buna göre Mustafa Kemal Paşa, Türkiye’nin güney sınırını, “İskenderun Körfezi’nin güneyinden, Antakya'dan Halep ile Katma İstasyonu arasındaki Cerablus köprüsünün güneyinde bulunan Fırat nehrine kavuşur. Oradan Dir'izor'a iner; ondan sonra doğuya uzatılarak Musul, Kerkük, Süleymaniye’yi içine alır." 74 şeklinde anlatmıştır. Anılan sınırlar içerisinde kalan ülke topraklarının Osmanlı topluluğundan ayrılmaz bir bütün olarak kabul edilmesi gerektiğini ifade eden Mustafa Kemal Paşa, milletin birliği koruyup bağımsızlığı için fedakârlıktan çekinmemesi hâlinde başarının muhakkak olacağını da dile getirmiştir. ${ }^{75}$

Mustafa Kemal Paşa, Ankara’ya gelen mebuslara da görüş ve düşüncelerini anlattıktan sonra "Misak-1 Millı̂” adıyla bir ortak metin kaleme alınmıştır. Kasım ayı içerisinde yapılan seçimlerde Anadolu'nun hemen her ilinde Müdafaa-i Hukuk Cemiyetlerinin aday gösterdiği

71 Selek, Anadolu İhtilali, 1: 328-333.

7227 Aralık 1919 tarihli tebliğ şu şekildedir: "Sivas’tan Kayseri yoluyla Ankara’ya hareket eden Heyet-i Temsiliye, bütün yol boyunca ve Ankara'da büyük milletimizin çok sıcak ve içten gelen vatanseverlik gösterileri arasında bugün şehre geldi. Milletimizin gösterdiği bu birlik ve kararlılık örneği, memleketimizin geleceğine güven konusundaki inançları sarsılmaz bir şekilde güçlendirici niteliktedir. Şimdilik Heyet-i Temsiliye'nin merkezi Ankara'dadır." Atatürk, Nutuk, 228.; Heyet-i Temsiliyenin Ankara'daki faaliyetleri için bkz. Cemil Özgül, Heyet- $i$ Temsiliye'nin Ankara'daki Çalışmaları (27 Aralık 1919-23 Nisan 1920) (Ankara: Atatürk Araştırma Merkezi Yayınları, 1989).; Ayrıca Heyet'in aldığı kararlar için bkz. Bekir Sıtkı Baykal, Heyet-i Temsiliye Kararları (Ankara: TTK Basımevi, 1974).; Uluğ İğdemir, Heyet-i Temsiliye Tutanakları, 2. Baskı, (Ankara: TTK Basımevi, 1989).

73 Kazım Karabekir'in telgrafı şöyledir: 'Kuva-yı Millîye’yi temsil eden yüksek heyetin, değil Ankara'ya, hatta Sivas’ın batısına bile geçmemesi görüşündeyim. Çünkü Doğu illerinin Kuva-yı Millîyesi demek olan bu heyetin bütün bütün uzaklaşması, dolayısıyla bu illetin teşkilatsız kalmasına yol açacaktır. Şimdiye kadar pek meşru ve mantıklı olarak yönetilmekte olan Millî Mücadele'nin, öteden beri her zaman her teşebbüsümüzü kötü görmek ve göstermek isteyen düşmanlarımıza karşı da eskiden olduğu gibi bir yerden yönetilmesi için, Heyet-i Temsiliye'nin Sivas'tan batıya geçmemesi görüşünde bulunduğumu arz ederim." Karabekir, İstiklâl Harbimiz, 1: 366-367.; Atatürk, Nutuk, 229.

74 Atatürk'ün Söylev ve Demeçleri, yay. haz: Ali Sevim, İzzet Öztoprak, Akif Tural, (Ankara: Atatürk Araştırma Merkezi Yayınları, 2006), 30-40.

75 Atatürk, Nutuk, 245-246. 
isimler mebus seçilmiştir. Seçilen isimler Aralık 1919 ile Ocak 1920 arasında ikişer üçer kişilik gruplar hâlinde Ankara'ya gelerek Heyet-i Temsiliye Başkanı Mustafa Kemal Paşa ile görüşmüşler ve kongrelerde alınan kararlar üzerinde mülakatlarda bulunmuşlardır. İşte bu mülakatlar sonucunda Misak-1 Millî metni son şeklini almış ve Heyet-i Temsiliye üyelerince imzalanarak Trabzon mebusu Hüsrev Sami Bey’e aracılığıyla İstanbul'a gönderilmiştir. Ahd-i Millî adıyla kaleme alınan altı maddelik bu metin, ${ }^{76} 17$ Şubat 1920 tarihli toplantının ikinci oturumunda Edirne Mebusu Şeref Bey tarafından okunmuş ve Misâk-1 Millî adıyla yayımlanmıştır. ${ }^{77}$ Bunun üzerine İngiliz kuvvetleri 15-16 Mart 1920'de İstanbul'u resmen işgal etmişlerdir. Ardından da Cemal Paşa, Mahmut Paşa, Rauf Bey gibi mebuslar ve birtakım aydınlar tutuklanıp Malta'ya sürgün edilmiştir. ${ }^{78}$ İstanbul hükümeti yayımladığı bir bildiri ile işgali halka duyurmuştur. ${ }^{79}$

İşgal hareketi derhal Ankara' da bulunan Mustafa Kemal Paşa'ya bir telgrafla bildirilmiştir. $\mathrm{O}$ da derhal vali ve komutanlar ile Müdafaa-i Hukuk Heyetlerine bir genelgeyle ${ }^{80}$ İtilaf Devletleri'nin silah zoruyla İstanbul'u işgal ettiklerini, bu durumdan faydalanmak isteyenlerin çıkabileceğini, yanlış hareketlere mahal verilmemesi gerektiğini ve Anadolu ve Rumeli Müdafaa-i Hukuk Cemiyeti'nin milleti aydınlatacağını bildirmiştir. Ayrıca İstanbul'da bulunan İngiliz, Fransız, İtalyan siyasi temsilcileri ile Amerikan siyasi temsilcisine birer protesto gönderen Mustafa Kemal Paşa, hiçbir kuvvetin bir milletin yaşama hakkına tecavüz edemeyeceğini ve bu olaydan doğacak olan tarihi sorumluluğa tüm dünyanın dikkatini çekmek istediğini vurgulamıştır. ${ }^{81}$ Mustafa Kemal Paşa, Heyet-i Temsiliye adına aynı gün yayınladığı bir başka bildiriyle, İtilaf Devletleri'nin İstanbul'u zorla işgal etmek suretiyle, Osmanlı Devleti'nin altı yüz yıllık hayat ve hâkimiyetine son verdiğini duyurmuş ve millet vatan savunmasına davet etmiştir. $^{82}$

76 Misak-1 Millî maddeleri için bkz. Meclis-i Mebusan Zabıt Ceridesi, 17 Şubat 1336 (1920), 1: 144-145. Ayrıca bkz. İhsan Ezherli, Türkiye Büyük Millet Meclisi (1920-1992) ve Osmanlı Meclis-i Mebusanı (1877-1920) (Ankara: TBMM Kültür, Sanat ve Yayın Kurulu Yayınları, 1992), 24.; Millî Egemenlik Belgeleri (Ankara: TBMM Basımevi, 2015), 32-38.; Selahattin Tansel, Mondros 'tan Mudanya 'ya Kadar (Ankara: MEB Yayınları, 1978), 3: 18-19.; Türk İstiklal Harbi, 2/2: 125-126.

77 Cevdet Küçük, "Misâk-i Millî”, İslam Ansiklopedisi (Ankara: TDV Yayınları, 2005), 30: 173-175.

78 Ayrıntılı bilgi için bkz. Bilal N. Şimşir, Malta Sürgünleri (Ankara: Bilgi Yayınevi, 1985), 173-175.

79 Bildiri şu şekildedir: "İtilaf Devletleri siyasi temsilcilerinin sabahleyin hükümete verdikleri notada ve bugünkü akşam gazetelerinde çıkan bildirisinde görüldüğü üzere İstanbul, bugünden itibaren geçici olarak askeri işgal altına alınmıştır. Hükümet kendine düşen vazifeleri yapacağı için halkın, kendi iş ve güçleriyle meşgul olmaları tavsiye olunur." Türk Istiklal Harbi, 2/2: 132.

80 Mustafa Kemal Paşa, Balıkesir'de bulunan 61. Fırka Kumandanlığına İstanbul'un işgalini şu şekilde duyurmuştur: “Bu sabah 16.3.1920 İngilizlerin Şehzadebaşı'ndaki karakolu askerimiz uykuda iken basarak altı kişiyi şehit ve on beş kadarını mecruh ettikten sonra, karakolu bir taraftan da Harbiye Nezaretini ve Tophane'yi ve Harbiye telgrafhanesini işgal ettikleri bildirildi. Bu harekâtı yapan, rıhtıma yanaşan İngiliz zırhlıları bahriye efradıdır. İstanbul'da fevkalade bir halin cereyan etmekte olduğu anlaşılıyor. Vaziyet, heyetimizce takip edilmektedir. İstanbul'la muhabere ve münasebette müteyakkız bulunulması arz olunur.” Özalp, Millî Mücadele, 1: 102-103.; Türk İstiklal Harbi, 2/2: 134-135.

81 Atatürk, Nutuk, 284-285.

82 Türk İstiklal Harbi, 2/2: 135. 
Osmanlı Devleti'nin ayakta kalıp yaşayacağı varsayımıyla Misâk-1 Millı̂’yi kabul eden Meclis-i Mebusan ${ }^{83}$ ise 18 Mart’ta son toplantısını yapmış ve bu tarihten itibaren çalışmalarına ara vermiştir. 11 Nisan 1920'de de Padişah, Meclis'i feshetmiştir. ${ }^{84}$ Padişah yayımladı $\breve{g} 1$ hatt-1 hümayunda Millîyetçilik hareketlerinin bir türlü önüne geçilemediğini vurgulamış ve ayaklanma olarak nitelediği Millî Mücadele hareketinin daha tehlikeli hâllere sebebiyet vereceğini ifade etmiştir. Damat Ferit Paşa ise aynı gün yayınladığı hükümet bildirisinde Ankara'yı fitne ve fesat çıkarmakla suçlamış, barış şartlarının daha da ağırlaşmasına sebep olduklarını iddia etmiştir. ${ }^{85}$ Bu sırada Mustafa Kemal Paşa'nın askerî mahkemece ölüme mahkûm edilmesi İstanbul ile Ankara arasındaki bağları iyice zayıflatırken, direniş hareketinin emperyalizm ve saltanat karşıtı, ulusal bir nitelik kazanmasına neden olmuştur. ${ }^{86}$ Ayrıca İngilizler bu eylemleriyle, önderlerini kaybeden Karakol Cemiyeti'nin Mim Mim Grubu adıyla Ankara'nın emrine girmesine vesile olmuşlardır. ${ }^{87}$

İşgalden 3 gün sonra Mustafa Kemal Paşa, valilikler, kolordu komutanlıkları ve bağımsız sancaklara yeni seçim hazırlıklarına başlanması için 12 maddelik bir talimatname daha göndermiştir. Devlet merkezinin korunması, milletin bağımsızlığı ve devletin kurtarılması tedbirlerini uygulamak üzere, millet tarafından olağanüstü yetkiler taşıyan bir meclisin Ankara' da toplantıya çağrılmış olduğunu ifade eden Mustafa Kemal Paşa, dağılmış milletvekillerinden Ankara'ya gelebilecek olanların da meclise katılımını zaruri görmüştür. ${ }^{88}$ Seçimlere derhal başlanmış ve 232 mebus seçilmiştir. Bunlara sonradan 92 mebusla, biri Yunanistan ve diğerleri Malta'dan gelen 14 mebusun da eklenmesi ile sayı 337'ye ulaşmıştır. ${ }^{89}$ Mustafa Kemal Paşa, 21 Nisan' da yayımladığı genelgede 23 Nisan Cuma günü, Ankara'da Büyük Millet Meclisi’nin açılacağını, vatanın istiklali, Hilafet ve Saltanat makamlarının kurtarılması gibi hayati görevleri bu meclisin üstleneceğini duyurduktan sonra, bu tebliğin memleketin her tarafına ulaştırılmasını istemiştir. Mustafa Kemal Paşa, ertesi gün yayınladığı genelgede ise askerî ve sivil bütün makamlarla bütün milletin tek yetkili merciinin Büyük Millet Meclisi olacağını ilan etmiştir. ${ }^{90}$ Böylece Anadolu ihtilalinin ilk önemli siyasi ayağı tamamlanmış, sıra askeri ve diplomatik ihtilalin gerçekleşmesine gelmiştir.

83 Hıfzı Veldet Velidedeoğlu, İlk Meclis (İstanbul: Cumhuriyet Yayınları, 1999), 12.

84 Ahmet Mumcu, "Misâk-1 Millî ve Anayasamız", Atatürk Araştırma Merkezi Dergisi 1/3 (1985), s. 813-830.

85 Padişah'ın Hatt-1 Hümayunu şöyledir: "Mütarekeden beri, siyasi durumumuz, gittikçe düzelmeye yüz tutmuşsa da "Milliyetçilik" adı altındaki karışıklıkların bir türlü önüne geçilememiştir. Bu ayaklanmaların devamı, Tanrı korusun, daha tehlikeli hallere sebep olacağı için bilinen tertipler hakkında kanun hükümlerinin uygulanması ve bütün milletin saltanat etrafinda toplanarak barışın bir an önce elde edilmesi en büyük emelimdir.” Ayrıca Damat Ferit Paşa'nın bildirisi için de bkz. Türk İstiklal Harbi, 2/2: 137-138.

86 Kemal H. Karpat, Türkiye'de Siyasal Sistemin Evrimi 1876-1980, çev. Esin Soğanc1lar, (Ankara: İmge Kitabevi, 2007), 24-25.

87 Erik Jan Zürcher, Terakkiperver Cumhuriyet Fırkası (İstanbul: Bağlam Yayınları, 1992), 32.

88 Atatürk, Nutuk, 287-288.

89 Tarık Zafer Tunaya, "Türkiye Büyük Millet Meclisi Hükümetinin Kuruluşu ve Siyasi Karakteri”, I..H.F.M. 23/34, 227-247.

90 Atatürk, Nutuk, 294-295. 


\section{TBMM Diplomasisi}

Mustafa Kemal Paşa, Büyük Millet Meclisi’nin açılışının ertesi günü gerçekleştirilen gizli oturumda ülkenin dört bir yanında işgallerin devam ettiğini belirtmiş ve bu durumda yapılacak iki şeyden birine karar vermek gerektiğini vurgulamıştır. Bunlardan birincisinin İstanbul hükümetinin yaptığı gibi İngilizlere esir olmak olduğunun altını çizen Mustafa Kemal Paşa, ikincisinin ise millet namus ve şerefiyle yaşatılmak isteniyorsa mevcut kuvvet ve vasıtaların icabına göre kullanılarak, düşmanın emellerini kırmak şeklinde hareket etmek olduğunu ifade etmiştir. Mustafa Kemal Paşa, işgal altında bulunan devletin merkezi için İstanbul demekle Londra demek arasında hiçbir farkın olmadığını da sözlerine eklemiştir. ${ }^{91}$ Aynı gün TBMM Başkanlık Divanı teşkil edilirken Mustafa Kemal Paşa da 110 oyla Meclis Başkanı seçilmiştir. ${ }^{92}$ Derhal bir önerge veren Mustafa Kemal Paşa, hükümet kurulmasının zorunluluğunu vurguladıktan sonra, geçici bir hükümet başkanı ya da Padişah vekili atamanın mümkün olmadığını ifade etmiştir. TBMM'nin üzerinde hiçbir gücün olmadığını belirten Mustafa Kemal Paşa, Meclis'in yasama ve yürütme yetkilerini elinde bulundurduğunu, Meclis'ten seçilecek bir heyetin hükümet işlerini yürütmesi gerektiğini ve Padişah ve Halife'nin de Meclis' in düzenleyeceği kanuni esaslar çerçevesinde yerlerini alacaklarını dile getirmiştir. ${ }^{93}$ Böylece hem Meclis hükümeti sistemi hem de güçler birliği prensibi resmen hayata geçirilmiş, Türk milletinin tek temsilcisinin Büyük Millet Meclisi olduğu tüm dünyaya ilan edilmiştir.

Mustafa Kemal Paşa, 1 Mayıs 1920 tarihli oturumda ise İstanbul hükümetinin bir ordusu bulunduğunu, ancak bu ordunun iş yapamaz halde olduğunu belirtmiş ve vatanın savunması görevinin doğrudan doğruya millete yöneldiğinin altını çizmiştir. Milletin düşman işgali altındaki yerlerde görevli kılınmasının mecburiyetini anlatan Mustafa Kemal Paşa, bu harekete Kuvayı Millîye dendiğini aktarmıştır. ${ }^{94}$ Meclis’te 2 Mayıs’tan itibaren İcra Vekilleri Heyeti teşkil edilirken, Millî Mücadele'nin bundan sonraki safhası bizzat Meclis eliyle ve daha sistematik bir şekilde sürdürülmüştür.

\subsection{Türk-Fransız İtilafnamesi ve Sevr'in Reddi}

Millî Mücadele döneminde Türk-Fransız münasebetleri, Fransız askerinin Anadolu'dan çıkarılması ve bir an önce iki ülke arasında barışın sağlanması amaçları etrafında şekillenmiştir. Mondros Mütarekesi ile birlikte Anadolu'nun güney kesimlerinde işgallere başlayan Fransız kuvvetleri uzun bir süre boyunca bölgedeki işgalleri devam ettirmiştir. Mustafa Kemal Paşa, buralarda topyekûn savaş vermek yerine Kuva-yı Millîye güçleriyle harekete geçilmesine karar vermiştir. Bunun için bir taraftan Batı Anadolu'daki Yunan ilerleyişi durdurulmaya çalışılmış, diğer taraftan da güneyde Fransızlarla mücadele edilmiştir. Mustafa Kemal Paşa, bölgeye gönderdiği cesur subaylar sayesinde Kilikya'da işgal kuvvetlerine karşı Millî teşkilatın

91 TBMM Gizli Celse Zabitları, 24 Nisan 1920, 1: 8.

92 TBMM Zabit Ceridesi, 24 Nisan 1920.

93 Atatürk, Nutuk, 300.

94 TBMM Gizli Celse Zabitları, 1 Mayıs 1920, 1: 6. 
kurulmasını sağlamış, bu kuvvetler yaptıkları baskınlar sayesinde 11 Şubat 1920'de Maraş'1, 8 Nisan'da Urfa'yı, 28 Mayıs'ta Toroslar'da Gülek Boğazı ve Toros tünellerini, daha sonra Haçin (Saimbeyli) ve Kozan'ı Fransız işgalinden kurtarmışlardır. Öte yandan Antep, Adana, Tarsus, Osmaniye taraflarında da emniyet bölgeleri oluşturulmuş, böylece Fransızlar Torosların güneyine çekilmek zorunda kalmışlardır. ${ }^{95}$

Güney cephesinde yaşanan işgalleri sonlandırmak ve Fransızlarla barış yaparak buradaki kuvvetleri Batı'ya sevk etmeyi düşünen Mustafa Kemal Paşa, Fransızları İngilizlerden ayırmak ve San Remo'da devam eden barış görüşmelerinde Türkler lehine olumlu bir etki yaratmak umuduyla tüm gücünü Kilikya'da Fransızlar ve Ermeniler üzerine seferber etmiştir. Mustafa Kemal Paşa, milis güçleri organize etmenin yanında, Suriye'deki Arapları Fransızlara karşı kışkırtmış ve Suriye'den Fransızlara gönderilen silahların akışını bir şekilde engellemiştir. Fransızlar bu durum karşısında Çukurova'daki gerginliği azaltmak için General Gouraud vasıtasıyla TBMM hükümeti ile görüşmenin yollarını aramışlar ve Mustafa Kemal Paşa'nın ulusal sınırlar içinde olan ve Fransız işgali altında bulunan bölgelerin tamamıyla boşaltılması talebiyle karşılaşmışlardır. Durum Paris’te müzakere edildikten sonra, barış koşulları onaylanmış ve 28 Mayıs 1920'de Ankara'ya bildirilmiştir. Buna göre 29 Mayıs gece yarısından itibaren iki taraf arasında 20 gün süre ile düşmanca tavırlar sona erecek ve bu süre içinde Pozantı, Sis, Antep, Maraş ve Urfa boşaltılarak, buraların güvenliği Türk jandarmasına bırakılacaktır. Ayrıca Fransızlar, Türk Millî hareketine karşı hiçbir davranışta bulunmayacak ve Millî Mücadelenin siyasi amaçlarını gayri resmî olarak destekleyeceklerdir. ${ }^{96}$ Fransızların 8 Haziran' da Zonguldak Ereğlisi'ne asker çıkarmaları üzerine bozulan bu anlaşma, Fransa'nın “de facto" (fiilî) olarak TBMM'yi tanıması açısından son derece önemlidir.

TBMM, bu süreçte bir taraftan işgal kuvvetleriyle, diğer taraftan da içeride baş gösteren isyanları bastırmakla uğraşmıştır. İşte bu durumda Türk milletine şartları gayet ağır bir barış antlaşmasının kabul ettirilmesi için uğraşan İtilaf Devletleri, 18 Nisan'da San Remo'da toplanarak aldıkları kararları iletmek üzere, ${ }^{97} 22$ Nisan'da Osmanlı Devleti'ni resmen konferansa davet etmişlerdir. 6 Mayıs'ta konferansa katılan Tevfik Paşa başkanlığındaki heyete, 11 Mayıs'ta Fransız Dışişleri Bakanı Alexandre Millerand tarafından barış anlaşması metni verilmiştir. Tevfik Paşa, barış şartları için devletin yıkılması ve Padişah'ın hukukunun imhası yorumunu yaptığı bir mektubu Damat Ferit Paşa’ya göndermiş ve anlaşmayı imzalamaya imkân olmadığını söylemiştir. ${ }^{98}$ TBMM üyeleri anlaşma hükümlerine var güçleriyle karşı

95 Tevfik Bıyıklığlu, "Başkumandan Atatürk’ün Kısa Bir Portresi”, Belleten XX/80 (1956), 701-735.

96 Salâhi R. Sonyel, Türk Kurtuluş Savaşı ve Dış Politika, 2. Baskı, (Ankara: TTK Yayınları, 1991), 2: 69-72.; Konu TBMM'de de tartışılmış ve 29 Mayıs tarihli gizli oturumda Erkân-1 Harbiye-i Umumiye Vekili İsmet (İnönü) Bey, anlaşmanın muhteviyatını anlatan bir konuşma yapmıştır. TBMM Gizli Celse Zabıtları, 29 Mayıs 1920, 1: 43.

97 San Remo görüşmelerinde Irak ve Filistin'de İngiliz, Suriye’de Fransız mandasının kurulması, Güney ve Güneydoğu Anadolu'da İtalyan ve Fransız nüfuz bölgelerinin oluşturulması, İngiliz himayesinde Kürdistan'ın teşkili, Doğu Anadolu'nun Ermenilere, İzmir ve Trakya'nın büyük bölümünü Yunanistan'a verilmesi ve Boğazların uluslararası bir komisyonca idaresi gibi kararlar alınmıştır. Tansel, Mondros 'tan Mudanya 'ya Kadar, 3: 149. 
koyacaklarını söylerken, Mustafa Kemal Paşa, “...milletimizin duygularını yansıtan bu heyecan ve üzüntüyü yitirmeden, bizi ölüme mahkûm eden düşmanlarımıza karşı daha kuvvetli ve daha etkin direnme yolları..." aranmasını istemiştir. ${ }^{99}$ Öte taraftan Padişah, İngiliz Kralına seslenmiş ve anlaşmanın koşullarının yumuşatılmasını, hiç olmazsa Türk halkının yaşadığı yerlerin paylaşılmaktan kurtarılması istemiştir. İngiliz Kralı 5 Haziran'da Türkiye'nin geleceğinin müttefik devletlerin elinde olduğunu ve adil bir barış anlaşması için uzun süreli bir sabır gösterdiklerini belirtmiştir. ${ }^{100}$ İçeride yoğun baskıya dayanamayan Damat Ferit Paşa ise istifa etmek mecburiyetinde kalmıştır. Ancak yeni hükümeti kurma görevi yine kendisine verilmiş ve kabine, anlaşmayı oy birliğiyle imzalayacak kişilerden oluşturulmuştur. Tevfik Paşa'dan sonra barış görüşmelerini yürütmek üzere heyet başkanı olarak Paris'e giden Damat Ferit Paşa, kendi hazırladıkları metni konferans heyetine vermiş ve Türkiye'nin savaşa girerek suç işlediğini, bu suçun İttihat ve Terakki yöneticilerinde olduğunu, bir Ermeni devletinin kurulması konusunda konuşmaya hazır olduklarını, fakat ülkenin parçalanmasına razı olamayacaklarını söylemiştir. ${ }^{101}$

İtilaf Devletleri diğer taraftan da Osmanlı Devleti'ne barış anlaşmasını imzalatmak için Yunan kuvvetlerinin işgallerini genişletmesini uygun görmüşlerdir. Yunan ordusu 22 Haziran 1920 tarihinde 60.000 kişilik kuvvetiyle taarruza geçerken Batı Anadolu'daki zayıf Kuva-yı Millîye cephesi kısa sürede çökmüştür. ${ }^{102}$ Bu gelişme üzerine İtilaf Devletleri, Damat Ferit Paşa'nın Paris'te sunduğu önerileri reddetmiş ve Tevfik Paşa'ya verilen metin üzerinde hiçbir değişiklik yapılamayacağını bildirmişlerdir. Anlaşmanın 27 Temmuz'a kadar imzalanmaması hâlinde de Türklerin ebediyen Avrupa'dan kovulacağı ve İstanbul'un Yunan askeri tarafindan işgal edileceği tehdidinde bulunmuşlardır. ${ }^{103}$ Diğer taraftan Yunan askerleri de Burhaniye, İvrindi, Soma, Akhisar, Salihli ve Nazilli hattını işgal ederken, iki hafta içinde Alaşehir-Bursa hattına kadar varmışlardır. Yunan kuvvetlerinin Doğu Trakya' da toprak kazanma peşine düşmeleri ise Millî Mücadeleye 4 ay kadar bir zaman kazandırmıştır. Yunanistan'da gerçekleştirilen seçimler ve hükümet değişikliği de 6 ay sürmüş ve Mustafa Kemal Paşa, bu zamanı lehine kullanarak Batı'da yeni bir ordunun kurulmasını sağlamıştır. ${ }^{104}$

Askerî mücadelenin yanında diplomatik ilişkiler devam ettirilmiş ve Adana Cephesi Kumandanlığı tarafından 6 Temmuz 1920 tarihinde Hariciye Vekâleti'ne gönderilen yazıda Fransa ile ilişkilerin kesilmesi niyetinde olunmadığ bildirilmiştir. ${ }^{105}$ Bir hafta kadar sonra, yani 14 Temmuz'da da TBMM tarafından Kastamonu Valiliği'ne gönderilen yazıda Fransızlarla iyi münasebetler kurulması yönünde talimat verilmiş, ${ }^{106}$ bununla birlikte İngiliz ve Fransız

99 TBMM Zabit Ceridesi, 22 May1s 1920, 2: 13-22.

100 Sonyel, Türk Kurtuluş Savaşı ve Dış Politika, 2: 81.

101 Turan, Siyasi ve Hukuki Açıdan Millî Mücadele, 74-75.

102 Bıyıklığlu, "Başkumandan Atatürk'ün Kısa Bir Portresi”, 701-735.

103 M. Cemil Bilsel, Lozan (İstanbul: Soysal Yayınları, 1998), 1: 342.

104 Bıyıklığlu, "Başkumandan Atatürk’ün Kısa Bir Portresi”, 701-735.

105 Başbakanlık Cumhuriyet Arşivi (BCA) Fon Kodu: 030.18.1.1, Yer Numarası: 1.3.15. (Bu dipnottan itibaren "Başbakanlık Cumhuriyet Arşivi" kısaltılarak "BCA" şeklinde kullanılacaktır. Eğik çizginin (/); sol tarafı fon kodunu, sağ tarafı ise yer numarasını ifade edecektir.)

106 BCA, 30.10/54.354.4 
uçaklarının Karadeniz sahillerindeki vilayetlere attıkları beyannamelere karşı halkın uyanık bulunması için genelge gönderilmiştir. ${ }^{107}$ Ancak İstanbul hükümeti, 20 Temmuz günü "Ya İstanbul'da ve Millî beşiğimiz olan Anadolu' da hâkim kalmak suretiyle küçük, fakat yine bir devlet hâlinde bulunmak veyahut yapılan teklifi reddederek Osmanlı Devleti'nin hayatına son vermekten başka çare olmadığı” gerekçesiyle barış anlaşmasının imzalanmasına karar vermiştir. Böylece 10 Ağustos günü Paris'e giden ve Hâdi Paşa, Tevfik Bey ve Reşat Halis Bey’den oluşan heyet, Sevr (Sevres) Müessese-i Sınâiyyesi Dairesinde sunulan barış anlaşmasını imzalamıştır. ${ }^{108}$ İmzalanan Sevr Anlaşması, İstanbul hükümetinin Türk milletini temsil etmediği gerekçesiyle TBMM tarafindan kabul edilmezken, Şark Cephesi Kumandanı Kazım Karabekir'in 17 Ağustos tarihli 'Sevr anlaşmasını imzalayanların ve Saltanat Şûrası'nda olumlu oy kullananların vatan haini ilan edilmelerine dair teklifi”, 19 Ağustos’ta TBMM üyeleri tarafından oy birliği ile kabul edilmiştir. ${ }^{109}$ Sonraki yıllarda da bu anlaşmayı imzalayanlar unutulmamış, 30 Ocak 1923 tarihinde Damat Ferit kabinesinde bulunanlar ile Saltanat Şûrası üyelerine hiçbir suretle para verilememesi karara bağlanmıştır. ${ }^{110}$ Ayrıca gıyaben mahkûm olan Damat Ferit ve diğer üyeler hakkındaki kararın tebliğinin savcılık kanalıyla yapılması uygun görülmüştür. ${ }^{11}$

\subsection{Londra Konferansı}

İtilaf Devletleri'nin Osmanlı topraklarını aralarında paylaşma konusunda tam bir anlaşmaya varamamış olmaları Sevr Anlaşması'nın yumuşatılmasını gündeme getirirken, ${ }^{112}$ özellikle Fransızlar anlaşma maddelerinin değiştirilmesi noktasında daha olumlu bir tavır takınmıştır. Fransa Dışişleri Bakanlığı Genel Sekreteri Berthelot, 7 Aralık 1920 tarihli telgrafında İngilizlerin Sevr'in revize edilmesine karşı çıkmalarına rağmen, kendilerinin Türklerin geleceğini Bolşeviklere teslim etmemeye kararlı olduklarını bildirmiştir. İngilizler ise direnmeye devam etmiş ve Lloyd George, 22 Aralık’ta Parlamento'da yaptığı konuşmada Mustafa Kemal Paşa’yı "asi”" ilan edip Yunan işgalini desteklemeye devam etmiştir. ${ }^{113}$ Aslında Fransızların, özellikle Ortadoğu'da İngiliz yayılmacılığından rahatsız oldukları çok önceden biliniyor ve buna göre de yeni politikalar üretiliyordu. Aralık 1919'da Suriye'deki Fransız Yüksek Komiseri George Picot'nun Sivas'a gelip ekonomik ayrıcalıkların devam etmesi karşılığında Adana, Antep ve Urfa'nın boşaltılacağı yönünde Mustafa Kemal Paşa ile pazarlığa tutuşması da bunun bir göstergesiydi.

Sevr Anlaşması, Türk-Fransız münasebetlerine de yeni bir boyut kazandırmış, Mustafa

107 BCA, 30.10/54.354.11

108 Turan, Siyasi ve Hukuki Açıdan Millî Mücadele, 75-76.; Sevr Anlaşmasının tam metni için bkz. Nihat Erim, Devletlerarası Hukuku ve Siyasi Tarih Metinleri (Ankara: Ankara Üniversitesi Hukuk Fakültesi Yayınları, 1953), 1: 524-691.; Tansel, Mondros 'tan Mudanya'ya Kadar, 3: 175-177.

109 TBMM Zabit Ceridesi, 19 Ağustos 1920, 3: 333.

110 BCA, 30.18.1.1/6.47.9

111 BCA, 30.10/204.394.28

112 Sadi Irmak, Atatürk Devrimleri Tarihi (İstanbul: Fatih Yayınevi, 1973 ), 87.

113 Yavuz, Kurtuluş Savaşı Döneminde Türk-Fransız İlişkileri, 105. 
Kemal Paşa’nın İngiltere ile Fransa’yı birbirine düşürme planı 1921 yılı başlarından itibaren yeniden gündeme gelmiştir. Bu amaçla Mustafa Kemal Paşa, Mısır ordusunda görevli Yarbay Hayri’yi Gouraud ile ateşkes görüşmeleri yapmak üzere Ocak ayında Paris’e göndermiştir. Bu sırada TBMM hükümetinin yeni oluşturduğu ordunun 6-11 Ocak tarihleri arasında kazandığı I. İnönü muharebeleri, ${ }^{114}$ İtilaf Devletleri'ni 21 Şubat 1921'de Londra' da bir konferans toplamaya zorlamıştır. ${ }^{115}$ Aslında 1920 Eylül'ünde Ermenilerin Türk kuvvetleri tarafından yenilgiye uğratılması İngilizleri telaşlandırmış, İzmir çevresinde Yunan kuvvetlerinin de aynı hezimete uğramaları durumunda, Sevr Anlaşması'nda birtakım değişiklerin yapılabileceği gündeme gelmiştir. İngiliz Yüksek Komiseri Sir Horace Rumbold, 27 Kasım'da Lord Curzon'a değişiklik kaçınılmaz olursa müttefiklerin politikasını Anadolu’nun yatıştırılmasını hızlandırmak, Müttefiklerin en az zararla durumdan sıyrılmasını ve gayrimüslim azınlıkların gelecekteki mutluluğunu sağlamak şeklinde özetlemiştir. ${ }^{116}$

Londra Konferansı'nın toplanmasına sebep olarak TBMM hükümetinin askerî ve siyasi alanlarda elde ettiği başarılar gösterilebilir. Bu anlamda Çukurova bölgesinde Fransılarla girişilen çatışmalar ve elde edilen başarılar sonucunda imzalanan kısa süreli mütareke ile İnönü Muharebelerinin Millî Mücadele hareketine kazandırdığı prestij, Türklerin kolay kolay vatansız bırakılamayacağını göstermiştir. Öte yandan gelişen Türk-Rus ilişkileri İtilaf Devletleri'ni daha temkinli olmaya zorlamış, Anadolu'da olası Bolşevik teşkilatlanması Fransızları olduğu gibi İtalyanları da TBMM hükümetiyle yakınlaşmaya itmişstir. Mustafa Kemal Paşa da Fransa ve İtalya’yı İngiltere'den ayırmak için Roma ve Paris temsilcilerine gönderdiği talimatta Sevr'in kabul edilmeyeceğini ancak Fransa ve İtalya ile anlaşma yapmaya hazır olunduğunu bildirmiştir. Bu sırada Doğu Cephesi'nde Kazım Karabekir Paşa komutasındaki Türk kuvvetleri Ermenilerin eline geçmiş olan Sarıkamış ve Merdenek'i ve karşı taarruza devam ederek, 30 Ekim 1920'de Kars'1 geri almıştır. Böylece Doğu'da Ermeniler sorun olmaktan çıkartılarak, Misak-1 Millî sınırlarına ulaşılmış ve mütareke istemeye zorlanmışlardır. Varılan mutabakat neticesinde 3 Aralık 1920'de Ermenilerle TBMM hükümeti arasında Gümrü Antlaşması imzalanmış, önceden kaybedilen Kars, Sarıkamış, Kağızman, Kulp ve Iğdır yeniden Türk topraklarına katılmıştır. Bu antlaşmayla Doğu Cephesi kapanırken burada bulunan kuvvetlerin Batı Cephesi'ne gönderilmesi kolaylaşmıştır. ${ }^{117}$

İtilaf Devletleri'nin İtalya Dışişleri Bakanı Kont Sforza’nın önerisiyle Sevr’i yeniden görüşmek üzere Londra'da toplanma kararı, ${ }^{118}$ Fransa Başbakanı Briand'ın isteğiyle Türk ve

114 I. İnönü Muharebeleri ve sonuçları hakkında geniş bilgi için bkz. Türk Ístiklal Harbi, Batı Cephesi, 3. Baskı, (Ankara: Genelkurmay Basımevi, 1999), 2/3: 145-246.

115 Yavuz, Kurtuluş Savaşı Döneminde Türk-Fransız İlişkileri, 276.

116 Salâhi R. Sonyel, “İngiliz Yüksek Komiseri Sir Horace Rumbold’un Türk Ulusal Akımına Karşı Tutumu (19201923)", Belleten LVII/221 (1994), 159-184.

117 Turan, Siyasi ve Hukuki Açıdan Millî Mücadele, 81-100.

118 Yuluğ Tekin Kurat, "Mustafa Kemal's İnstructions (An İntercepted and Decyphered Telgram) to Bekir Sami in London-A Reassessment of the London Conference (21 February-12 March 1921) and its İmmediat Consequences", Belleten XLVIII/189-190 (1984), 55-88. 
Yunan temsilcilerine iletilmiştir. Briand, İstanbul ve Atina'daki temsilcilerine Türk tarafının Mustafa Kemal veya TBMM hükümeti yetkililerinin de Osmanlı delegasyonunda yer alması koşuluyla davet edildiğini ve Yunan hükümetinin de konferansa katılacağını bildirmiştir. ${ }^{119}$ Daveti alan Sadrazam Tevfik Paşa, 27 Ocak’ta Mustafa Kemal Paşa'yı telgrafla haberdar etmiştir. Mustafa Kemal Paşa ise verdiği cevapta Türkiye ile ilgili tüm sorunların çözüm yerinin TBMM olduğunu ifade etmiş ve Tevfik Paşa'yı kendileriyle birleşmeye davet etmiş, ${ }^{120}$ Padişahı da TBMM hükümetini resmen tanımaya davet etmiştir. ${ }^{121}$ Ertesi gün davetin doğrudan TBMM'ye yapılması gerektiğini bildiren Mustafa Kemal Paşa, Millî Hareketin İstanbul'a tabi olmayacağını ifade etmiştir. İki taraf arasındaki yazışmalar devam ederken bu sırada Ankara' da bulunan eski Sadrazam Ahmet İzzet Paşa'nın da aracılık teşebbüsü de başarısız olmuştur. ${ }^{122}$ Bununla birlikte 29 Ocak'ta Londra Konferansı'nda İstanbul hükümetinden ayrı bir heyetin TBMM hükümeti adına gönderilmesi kararı alınmıştır. ${ }^{123} \mathrm{Bu}$ heyete baş murahhas olarak Hariciye Vekili Bekir Sami Bey'in tayin edilmesi, ${ }^{124}$ onun yerine de Maliye Vekili Ferid Bey'in vekâlet etmesi uygun görülmüştür. ${ }^{125}$ Ayrıca Mustafa Kemal Paşa, 4 Şubat tarihli gizli oturumda “...düşmanlarımız tarafindan hükümet-i Millîmize doğrudan doğruya müracaat edilmedikçe murahhas izamında gayet dikkatli ve temkinli davranmak..." gereğinden bahsetmiş, TBMM hükümetinin resmen tanınmasına değin hiçbir teşebbüsten geri durmamakla beraber, beklemenin faydalı olacağını ifade etmiştir. ${ }^{126}$ Aslında Türk heyetinin Londra'ya gidişi Sevr'in tadili için değil TBMM hükümeti ve Misak-ı Millî’nin tüm Avrupa devletlerine tanıtılması amacıyla yararlı görülmüştür. Ayrıca TBMM hükümetinin dolaylı da olsa ilk kez Avrupa devletleri tarafından muhatap kabul edilmesi, Millî Mücadele hareketinin siyasi ve hukuki açıdan elini güçlendiren bir gelişme olmuştur.

Konferansta ilk sözü alan Yunan Başbakanı Kalogeropulos, arzu edilen barışın Türklere taviz vererek sağlanamayacağını, eğer Türkiye baş eğmezse daha fazla savaş tazminatı isteneceğini dile getirmiş ve Yunan kuvvetlerinin Mustafa Kemal'in gücünü tamamen dağıtabileceğini iddia

119 Londra Konferansı'nın toplanması 25 Ocak'ta Paris’te yapılan toplantı sonucunda kararlaştırılmış ve müzakerelerin esasını Sevr Anlaşması'nın teşkil edeceği belirtildikten sonra, Mustafa Kemal veya Ankara Hükümeti'nin belirleyeceği murahhasların da Türk heyetine dâhil edilmesi şart koşulmuştur. İzzet Öztoprak, "Londra Konferans1 ve Türkiye Meselesinin Cereyan-1 Müzakeratı", Atatürk Araştırma Merkezi Dergisi XI/33 (1995), 565-612.

120 Atatürk, Nutuk, 377-378.

121 Kurat, "Mustafa Kemal's İnstructions (An İntercepted and Decyphered Telgram) to Bekir Sami in London-A Reassessment of the London Conference (21 February-12 March 1921) and its İmmediat Consequences", 55-88.

122 Aracılık teşebbüsünü Ahmet İzzet Paşa şu şekilde anlatmaktadır: "BU durum karşısında ben aracılığa yeltendim. Bir yönden bu firsatı kaçırmamak için gerek Paşa, gerek diğer bakanlar nezdinde tavsiye ve temennilerde bulunduğum gibi, İstanbul'a da Meclis'in tasdiki için telgraf çektim. Telgrafın ilk müsveddesi Paşa tarafından değiştirilmek istendi. Ben bunu kabul etmedim, ama ikisinin ortası bir telgraf yazdım. Bunun değiştirilmesi istendiyse de razı olmadım. Bu telgraf kendileri tarafından şifre edilerek gönderildi. Gerek Tevfik Paşa'dan alınan cevaptan, gerek geri dönüşümüzde çıkardığımız anlamdan İstanbul ve özellikle Padişahça teklifimizin öfke doğurduğu anlaşıldı. Ahmet İzzet Paşa, Feryadım, 2: 105.

123 BCA, 30.18.1.1/2.33.9

124 BCA, 30.18.1.1/2.33.14

125 BCA, 30.18.1.1/2.33.15

126 TBMM Gizli Celse Zabitlarl, 4 Şubat 1921, 1: 379. 
etmiştir. Ancak Fransa Başbakanı Briand, Türk ordusunun küçük görülmemesi gerektiğini, kendilerinin Çukurova' da buna bizzat tanıklık ettiklerini anlatmıştır. ${ }^{127}$ Konferansın 23 Şubat oturumunda Tevfik Paşa, sözü Türk milletinin gerçek temsilcisi olan TBMM delegesi Bekir Sami Bey’e vermiştir. Bekir Sami Bey, ilk olarak Türklerin ayrı bir millet olarak varlıklarını sürdürebilmeleri için Türk milletinin ekonomik ve siyasi hayatını sona erdirecek olan Sevr Anlaşmasının yürürlükten kaldırılması gerektiğini söylemiştir. Lloyd George'un ısrarla Sevr'in kabul edilip edilmeyeceğini sorması üzerine, Mustafa Kemal Paşa'ya durumu bildiren Bekir Sami Bey, iktisadi ve mali meselelerde Türk ilkelerinin değiştirilemeyeceği, Türk Millî emellerinin güvence altına alınması şartıyla anlaşmanın adının pek de önemli olmadığı cevabını almıştır. ${ }^{128}$ Aslında Türk tarafının istekleri Sevr'in tamamen reddedilmesi anlamına gelirken, konferans 20 günün ardından herhangi bir sonuç alınamadan, Türk ve Yunan taraflarına yeni önerilerde bulunularak dağılmıştır. ${ }^{129} \mathrm{Bu}$ duruma Türk heyetinin Misak-1 Millî’de ısrar etmesi de etkili olurken Bekir Sami Bey, Yunanistan’1 yalnız bırakmak için İngiliz, Fransız ve İtalyan temsilcileriyle genel barış görüşmelerinin dışında görüşmeler yapmış ve çeşitli anlaşmalar imzalamıştır. ${ }^{130} \mathrm{Bu}$ anlaşmaların TBMM hükümeti ile İtilaf Devletleri arasında daha sonra imzalanacak anlaşmalara zemin hazırladığı söylenebilir.

\subsection{Ankara İtilafnamesi}

Londra Konferansı'nda Bekir Sami Bey'in Fransızlarla yaptığı anlaşmayla çatışmalara son verilmesi ve esir mübadelesi yapılması, halkın ve silahlı çetelerin silahtan arındırılması, çatışmaların sona erdirilmesinden 1 ay sonra Fransızlar tarafından işgal edilen toprakların boşaltılması gibi konularda görüş birliğine varılmıştır. Ayrıca Türk-Fransız ekonomik iş birliğinin sağlanması da öngörülürken, asıl önemli gelişme Suriye sınırına ilişkin varılan mutabakat olmuştur. ${ }^{131}$ Ancak Bekir Sami Bey, bu anlaşmaları kendi hükümetine danışmadan imzalamış, bunun için de TBMM'de büyük tartışmalar yaşanmıştır. 17 Mart 1921 tarihli gizli oturumda Mersin Mebusu İsmail Safa Bey, anlaşmaya “...Fransızlarla bir muahede şekline girmiş olan şeyi münakaşa etmek istemiyorum. Çünkü esasen bizim bunu kabul edemeyeceğimizi bir buçuk seneden beri her yerde, her noktada mütemadiyen iddia ettik. Biz hayat istiyoruz, yaşamak istiyoruz." şeklinde yaklaşırken, anlaşmayı kimsenin imza etmeyeceğini düşündüğünü belirtmiştir. Yozgat Mebusu İsmail Fazıl Paşa ise “... Ne istiyorsunuz dedikleri zaman, verilecek cevap gayet basit idi: Bizim Misak-1 Millîmiz vardır” ifadeleriyle anlaşmaya karşı çıkmıştır. ${ }^{132}$ Aslında bu anlaşma Mustafa Kemal Paşa'nın 1 Mart'ta Bekir Sami Bey’e gönderdiği Sevr'in tartışma konusu yapılmayarak kesinlikle reddedilmesi ve Misak-1 Millî prensiplerine

127 Sonyel, Türk Kurtuluş Savaşı ve Dıș Politika, 2: 126.

128 Turan, Siyasi ve Hukuki Açıdan Millî Mücadele, 108-111.

129 Bu yeni öneriler için bkz. Öztoprak, "Londra Konferansı ve Türkiye Meselesinin Cereyan-1 Müzakeratı”, 565-612.

130 Sonyel, Türk Kurtuluş Savaşı ve Dış Politika, 2: 127-132.

131 Yavuz, Kurtuluş Savaşı Döneminde Türk-Fransız İlişkileri, 114-116.

132 Konu ile ilgili tartışmalar için bkz. TBMM Gizli Celse Zabıtları, 17 Mart 1921, 1: 3-9. 
sadık kalınarak kesinlikle sınırların aşılmaması talimatnamesine de ters düşmüştür. ${ }^{133}$ Zira Mustafa Kemal Paşa, Londra' da imzalanan anlaşmaları "Sevr projesini müteakip beyinlerinde akdettikleri 'Accord Tripartite' tesmiye olunan ve Anadolu'yu menatık-1 nüfuza taksim eden itilafnameyi başka namlar altında hükümet-i millı̂yemize kabul ettirmek maksadına matuf” olarak değerlendirmiştir. ${ }^{134}$ Bu yüzden adı geçen anlaşma, TBMM tarafından gayr-i kabil-i itilafname sayılarak reddedilmiştir. Bunun üzerine Bekir Sami Bey’in 8 Mayıs 1921 tarihinde yazdığı istifa dilekçesi 12 Mayıs'ta TBMM'de oylanarak kabul edilmiştir. ${ }^{135}$

Türk-Fransız anlaşmasının TBMM tarafından reddedilmesi iki ülke arasındaki ilişkileri kısa süreliğine de olsa olumsuz anlamda etkilemiştir. Fakat İngiliz desteğiyle 23 Mart'ta tekrar harekete geçen Yunan kuvvetlerinin İnönü mevkiinde ikinci kez bozguna uğratılması, ${ }^{136}$ bir taraftan TBMM hükümetinin elini güçlendirmiş, diğer taraftan da ekonomik sıkıntı içinde olan Fransa'yı Türklerle uzlaşmaya itmiştir. ${ }^{137}$ Bu gelişmelerin yaşanmasında kuşkusuz Sovyetlerle yapılan 16 Mart 1921 tarihli Moskova Antlaşması'nın da etkisi olmuştur. Böylece TBMM hükümeti Fransızlarla görüşmek üzere Mayıs ayı ortalarında Dışişleri Bakanlığı Hukuk Danışmanı Münir (Ertegün) Bey’i Adana'ya göndermiştir. Burada Türk tarafının önerileri pek dikkate alınmazken, iki taraf arasındaki görüşmeler kısa süre sonra yeniden başlamıştır. Fransa Başbakanı Briand tarafından TBMM hükümeti ile görüşmek üzere görevlendirilen Franklin Bouillon, 9 Haziran'da Ankara'ya ulaşmış ve 13 Haziran günü Mustafa Kemal Paşa'nın yanında Dışişleri Bakanı Yusuf Kemal (Tengirşenk) ve Fevzi Paşa’nın hazır bulunduğu bir toplantıya katılmıştır. Bouillon, burada Londra'da varılan anlaşmanın esas alınmasını talep etmiş, ancak Mustafa Kemal Paşa'nın Misak-1 Millî noktasında taviz vermez tutumu karşısında, Misak-1 Millî metnini incelemek üzere görüşmelere ara verilmesini istemişstir. Bundan sonraki görüşmelerin odak noktası Misak-ı Millî olurken, Fransızlar, Türkleri anlaşmaya zorlamanın anlamsız olduğunu anlamışlardır. ${ }^{138}$ Diğer taraftan İtilaf Devletleri'nin 18-19 Haziran 1921 tarihlerinde Türk-Yunan savaşında arabuluculuk yapmak üzere Paris’te toplanmaları Yunan tarafında hoş karşılanmamış ve 5 Temmuz'da Yunan kuvvetleri tekrar taarruza geçmiştir. Eskişehir, Kütahya ve Afyon arasındaki bölgeler Yunan kuvvetlerinin eline geçerken, Türk ordusu durumunu güçlendirmek için 25 Temmuz'da Sakarya Nehri'nin doğusuna çekilmek zorunda kalmıştır. Bu durum karşısında TBMM hükümeti, 5 Ağustos’ta Mustafa Kemal Paşa'ya

133 Kurat, Mustafa Kemal's İnstructions (An İntercepted and Decyphered Telgram) to Bekir Sami in London-A Reassessment of the London Conference (21 February-12 March 1921) and its İmmediat Consequences", 55-88.

134 Atatürk, Nutuk, 400.

135 Bekir Sami Bey'in istifa dilekçesi şöyledir: "Gerek akdetmiş olduğum itilafnameler ve gerek siyaset-i hariciyemizde Heyet-i Vekile ile bendeleri arasında bâriz bir surette ihtilâf-1 içtihad hâsıl olmuştur. Şu şerait dâhilinde bendelerinin Hariciye Vekâleti gibi siyaset-i umumiyenin nâzımı olması icap eden bir makamda kalması câlib-i mahazir olduğundan Vekâlet-i Hariciyeden istifamın kabul buyurulmasını talep ve rica eylerim efendim." TBMM Gizli Celse Zabitlarl, 12 Mayıs 1921, 2: 72-78.

136 II. İnönü Muharebeleri ve sonuçları hakkında ayrıntılı bilgi için bkz. Türk Ístiklal Harbi, 2/3: 247-516.

137 Sonyel, Türk Kurtuluş Savaşı ve Dış Politika, 2: 198.

138 Yavuz, Kurtuluş Savaşı Döneminde Türk-Fransız İlişkileri, 124-136. 
Başkomutanlık yetkisi vermiştir. ${ }^{139}$ Mustafa Kemal Paşa, Başkomutan sıfatıyla 7-8 Ağustos'ta yayınladığı Tekâlif-i Millîye emirleriyle ordunun ihtiyaçları için milletten yardım istemiştir. Böylece 23 Ağustos'ta başlatılan meydan muharebesi, 13 Eylül'de Sakarya'nın doğusunda tek bir Yunan askeri bile bırakılmadan büyük bir zafere dönüşmüştür. ${ }^{140}$

Sakarya'daki başarı, Millî Mücadele açısından iç ve dış dengelerin değiştiği önemli bir dönüm noktası olmuştur. Artık Türk milleti düşman karşısında inisiyatifi ele alırken, özellikle Fransa ile yürütülen barış görüşmelerinin hız kazanmasına da vesile olmuştur. Fransız temsilci Bouillon ikinci kez Ankara'ya gelirken, 24 Eylül'de Yusuf Kemal Bey, Münir Bey ve Ali Fethi Bey’den oluşan bir heyetle görüşmeleri sürdürmüştür. Görüşmeler 20 Ekim'de iki taraf arasında Ankara İtilafnamesinin imzalanmasıyla son bulmuş ve nihayet Türk-Fransız savaşı sona ermiştir. ${ }^{141}$ Böylece Fransızlar 4 Kasım'da işgal ettikleri yerleri boşaltmaya başlamışlar ve 1 Aralık’ta Türk kuvvetleri Adana'daki resmi daireleri işgal etmiştir. 20 Aralık’ta buradaki Fransız kuvvetleri şehri terk ederken, 20 Aralık'ta da Antep düşman işgalinden kurtulmuştur. ${ }^{142}$

\subsection{Mudanya Mütarekesi}

Ankara İtilafnamesi, hem bir İtilaf Devletiyle imzalanması hem de güney sınırındaki sorunların büyük oranda ortadan kaldırılması açısından TBMM hükümetini siyasi manada çok rahatlatmıştır. Millı̂ Mücadele hareketi ve TBMM hükümetinin İtilaf bloğuna karşı ilk büyük diplomatik başarısı sayılabilecek bu antlaşma, ulusal güçlerin topyekûn Batı cephesine yönlendirilmesinde önemli bir yer tutmuştur. Kuşkusuz antlaşmanın bir başka önemli boyutu da İtilaf Devletleri arasındaki görüş ayrılıklarının artması ve artık Sevr Anlaşması'nın Türk milletine kabul ettirilemeyeceğinin anlaşılmasıdır. Artık bir İtilaf Devleti Türk milletinin haklı davası olan Misak-ı Millî’yi tanımış ve savaş alanlarında kazanılan askerî başarıların masa başında diplomatik mücadeleyle taçlandırılabileceği gösterilmiştir. Diğer yandan Fransa'dan alınan askerî yardım sayesinde düzeni ordunun birtakım ihtiyaçları da karşılanmıştır. ${ }^{143}$ Elde edilen bu diplomatik başarıyı uluslararası kalıcı bir barışa dönüştürmek isteyen TBMM hükümeti, Aralık 1921'de Ferit Bey'i Fransa'da, Şubat 1922'de ise Dışşsleri Bakanı Yusuf Kemal Bey'i önce Fransa, sonra da İngiltere'de temaslarda bulunmak üzere Avrupa'ya göndermiştir. Yusuf Kemal Bey’in temaslarından sonra, özellikle İngiltere'nin Misak-1 Millî’yi tanımaya ve Anadolu'nun boşaltılmasına yanaşmaması TBMM'yi kesin bir askeri zafer alarak, masaya oturmaya zorlamıştır. ${ }^{144}$

139 TBMM Gizli Celse Zabitlart, 5 Ağustos 1921, 2: 164-185

140 Sakarya Meydan Muharebesi ve sonuçları hakkında detaylı bilgi için bkz. Türk Ístiklal Harbi, Batı Cephesi, (Ankara: Genelkurmay Basımevi, 1973), 2/5/2: 3-278.

141 Ankara Anlaşması maddeleri için bkz. Düstur, Üçüncü Tertip, (İstanbul: Milliyet Matbaası, 1929), 2: 152-171.; Yavuz, Kurtuluş Savaşı Döneminde Türk-Fransız İlişkileri, 145-148.

142 Selâhattin Tansel, Mondros 'tan Mudanya'ya Kadar (Ankara: MEB Yayınlar1, 1978), 4: 47.

143 Yavuz, Kurtuluş Savaşı Döneminde Türk-Fransız Ilişskileri, 149.

144 Tansel, Mondros 'tan Mudanya'ya Kadar, 4: 114-117. 
Sakarya zaferi düşmanın yurttan çıkarılması noktasında ümitleri iyice artırırken, 22 Mart 1922'de İngiltere, Fransa ve İtalya dışişleri bakanları, Türk ve Yunan taraflarına ateşkes çağrısında bulunmuştur. 24 Mart’ta ise Mustafa Kemal Paşa, Bakanlar Kurulu'na “Esas itibariyle, İtilaf Devletleri dışişleri bakanlarının ortaklaşa yaptıkları ateşkes teklifini kabul etmemek veya herhangi bir şekilde bu teklife yanaşılmıyor ve güven gösterilmiyor hissini verecek gibi davranmak doğru değildir.” ifadelerini kullandıktan sonra ateşkes teklifini iyi karşılamak gerektiği üzerinde durmuştur. Mustafa Kemal Paşa devamla "Bundan dolayı vereceğimiz karşılık olumsuz değil, olumlu olacaktır. İtilaf Devletleri'nde iyi niyet yoksa olumsuz davranış onlardan gelmelidir. Yalnız, biz, onların ileri sürdüğü şartları kabul edemeyeceğimizden, karşı şartlar ileri süreceğiz." şeklinde konuşmuştur. ${ }^{145}$ Ancak İtilaf Devletleri, Türk tarafının cevabını bile beklemeden 26 Mart'ta bu defa yapılacak barışın şartlarını deklare etmişlerdir. Bunun üzerine Ankara Hükümeti, ateşkese karşılık Anadolu'nun Yunan kuvvetlerince boşaltılmasını şart koşmuştur. Bu şartın kabul edilmeyeceği 15 Nisan’da bildirilirken, tahliyenin barış anlaşması hükümlerinin tamamının kabulüyle mümkün olacağı vurgulanmıştır. ${ }^{146}$

Hemen taarruz edilmesi konusunda türlü eleştiriler ve çekinceler bulunsa da Mustafa Kemal Paşa ile Batı Cephesi Komutanı İsmet Paşa arasındaki 3 Temmuz tarihli şifreli telgraflarda, planı konusunda görüş birliğine varılan harekâtın başarısı, ani olmasına bağlanmıştır. ${ }^{147} 30$ Temmuz'da Genelkurmay Başkanı Fevzi Paşa ve Millî Savunma Bakanı Kazım Paşa’nın da plana mutabık kalmasıyla durum değerlendirmesinin ardından, taarruz harekâtının Ağustos ayının sonlarına doğru yapılması kararlaştırılmıştır. Bunun üzerine, Garp Cephesi Komutanı İsmet Paşa, 6 Ağustos'ta ordularına taarruz emri vermiştir. 13 Ağustos'ta ise Fevzi Paşa cepheye gitmiştir. Mustafa Kemal Paşa da Çankaya'da bir çay ziyafeti tertip edildiğini ajansların ilan etmesinden bir gün önce, gece otomobille yola çıkarak 20 Ağustos'ta Akşehir'e varmıştır. ${ }^{148}$

Akşehir merkezli ve büyük bir gizlilik içinde yürütülen taarruz çalışmaları, çok geçmeden, 26 Ağustos 1922 sabahı topçu ateşiyle birlikte fiilen harekâta dönüşmüştür. 30 Ağustos’ta düşmanın ana kuvveti imha edilirken, Yunan ordusunun Başkomutanı General Trikopis de esir alınmıştır. Başkomutan Mustafa Kemal Paşa, Büyük Taarruz harekâtını, “26/27 Ağustos günlerinde, yani iki gün içinde, düşmanın Karahisar'ın güneyinde $50 \mathrm{~km}$ ve doğusunda 20$30 \mathrm{~km}$ uzunluğundaki müstahkem cephelerini düşürdük. Yenilen düşman ordusunun bütün kuvvetlerini, 30 Ağustos'a kadar Aslıhanlar yöresinde kuşattık. 30 Ağustos’ta yaptığımız savaş sonunda (Buna Başkomutan Muharebesi adı verilmiştir), düşmanın ana kuvvetlerini yok ettik ve esir aldık" şeklinde özetlemiştir. ${ }^{149}$

İzmir'e doğru kaçan diğer kuvvetlere de firsat verilmemesi amaciyla derhal takibat başlatılmış, Uşak, İnegöl, Yenişehir, Kula, Alaşehir, Salihli gibi yerler geri alındıktan sonra,

145 Atatürk, Nutuk, 439.

146 Turan, Siyasi ve Hukuki Açıdan Millî Mücadele, 182-183.

147 İsmet İnönü, Defterler (1919-1973), haz. Ahmet Demirel, 3. Baskı, (İstanbul: Yapı Kredi Yayınları, 2008), 1: 29.

148 Bilsel, Lozan, 1: 427-428.

149 Atatürk, Nutuk, 456. 
nihayet 9 Eylül günü Türk süvari birlikleri İzmir'e girmiştir. ${ }^{150}$ Zafer haberi kısa sürede tüm yurtta sevince sebep olurken, On Birinci Yunan Alayı da Mudanya önlerinde esir edilmiştir. Bunun üzerine Yunan halkına hitaben bir bildiri yayınlayan Kral Konstantin, "Kahraman ordumuz bir felakete uğradı. Fakat düşmanın bile beklemediği bu felaket, sancağımızın şanını eksiltmez. Bilakis, bize, fevkalade sabır ile tahammül etmek vazifesini emreder." ${ }^{\text {"151 }}$ sözleriyle Yunan ideallerinin Anadolu topraklarından atıldığını kabul etmiştir.

Büyük Taarruz ve ardından gelen Türk zaferi sonrasında Trakya'nın hâlen işgal altında bulunması İngilizlerle savaş ihtimalini gündeme getirirken, bu durum İngiltere Başbakanı Lloyd George'un da tedirgin olmasına sebep olmuştur. Lloyd George, “....Avrupa’yı Asya' dan ayıran Ak ve Karadenizleri birleştiren derin tuzlu su yolu birinci derecede ehemmiyeti haiz cihan menfaatlerini, Avrupa menfaatlerini ve İngiliz menfaatlerini alakadar eder" şeklinde yayınladığ 1 bildiri ile Avrupalı devletler ve dominyonlardan Boğazların korunması için takviye destek istemiştir. ${ }^{152}$ Ancak kimi ülkeler bu teklife sıcak bakarken, kimileri de teklifi geri çevirmiştir. Hatta Paris’ten gelen bir başka telgrafta "Fransa her türlü maceradan kaçınmak fikrindedir" ifadeleri kullanılmıştır. ${ }^{153}$ Lloyd George'nin 16 Ekim'de seçim konuşması sırasında kullandığ "Yunan yenilgisinden sonra durum çok tehlikeli idi. Türkler üzerimize yürüdüler. Fransızlar geri çekildiler. İtalyanlar da onlar gibi hareket ettiler. Farz edelim ki biz de Fransızlar gibi yapsaydık, o zaman Kuva-yı Millîye Çanakkale'ye yerleşecek ve oradan atacakları son adım boğazları geçmek olacaktı. Eğer Mudanya Konferansı'nda bu isteğe muvafakat etmeseydiler, onları acaba yerlerinden kim çıkarabilirdi. Zannederim hiç kimse!"154 ifadeleri ise zaferin İngilizler üzerinde uyandırdığı etkiyi göstermesi bakımından dikkate değerdir.

Bu gelişmelerin ardından Fransız Komiseri Genaral Pele'nin Mustafa Kemal Paşa'ya güvenli bölgeye çekilme tavsiyesi, Millî Hükûmetin böyle bir bölge tanımadığı ve Trakya da kurtarılmadıkça ordunun durmayacağı karşılığını bulmuştur. Bu bağlamda Türk ordusunun her başarısından sonra ateşkes için harekete geçen İtilaf Devletleri, bu aşamadan sonra da mütareke isteminde bulunmuşlardır. Ancak Mustafa Kemal Paşa ve Hükûmet, 29 Eylül'de İtilaf Devletleri dışişleri bakanlarına verdikleri notada Edirne dâhil, Meriç'e kadar Trakya'nın boşaltılması şartıyla masaya oturulabileceğini bildirmiştir. Şartın kabul görmesi üzerine de 3 Ekim 1922 Salı günü, öğleden sonra saat 3’te Mudanya Konferansı toplanmıştır. ${ }^{155}$

Konferansta Türkiye’yi İsmet Paşa temsil ederken, yanında ise Batı Cephesi Kurmay Başkanı Asım (Gündüz) Bey, Yarbay Tevfik (Bıyıklığlu) Bey, Binbaşı Seyfi (Düzgören) Bey ve Kızılay İkinci Başkanı Hamit Bey ile 2 yazman görevlendirilmiştir. Öte yandan Genelkurmay Başkanı Fevzi Paşa ile Refet (Bele) Paşa’nın da delegasyona yardım için

150 Durmuş Yalçın vd., Türkiye Cumhuriyeti Tarihi (Ankara: Atatürk Araştırma Merkezi Yayını, 2005), 1: $306-313$.

151 Ali Naci Karacan, Lozan Konferansı ve Ísmet Paşa, 3. Baskı, (Ankara: Bilgi Yayınevi, 1993), 19.

152 Bayur, Türkiye Devleti'nin Dış Siyasası, 118.

153 Karacan, Lozan Konferanst ve İsmet Paşa, 20.

154 Yakup Kadri Karaosmanoğlu, Vatan Yolunda (İstanbul: İletişim Yayınları, 1999), 176.

155 Yalçın vd., Türkiye Cumhuriyeti Tarihi,1: 320-322. 
Mudanya'da kalmaları uygun görülmüştür. Buna benzer görüşmelerde olduğu gibi, Anlaşma Devletleri de asker kökenli temsilciler seçmiştir. İngiltere’yi işgal orduları komutanı General Harrington, Fransa'yı General Charpy, İtalya'yı General Monbelli temsil etmişlerdir. Ancak asıl savaşan taraf, yani Yunanistan, General Mazarakis ile Albay Sariyanis’i temsilci olarak göndermesine rağmen, onların yerine konferans sözcülüğünü İngilizler yapmıştır. ${ }^{156}$

İsmet Paşa'nın oturumu açmasından sonra söz alan Harrington, konferansın mevzuunun muhasamatı durdurmak, Trakya'dan Yunan ordusunun çekileceği hattı belli etmek ve yakında toplanacak barış konferansına yol açmak oluğunu belirtmiştir. Harrington ayrıca aralarında mutabakata vardıkları 10 maddelik projeyi de tartışmaya sunup, görüşmelere başlanmasını istemiştir. Fakat bu projede Türk heyetinin dikkatini, Şarki Trakya'nın Yunanlar tarafından tahliyesinin zikredilmesi, fakat bu toprakların Türklere verilmesinden söz edilmemesi ile Meriç’in batısında ve Edirne'nin bir mahallesi olan Karaağaç'tan hiç bahsedilmemesi hususları çekmiştir.

Tam da bu sırada Başkomutan Mustafa Kemal Paşa'dan Karaağaç'ın Edirne'nin bir mahallesi kabul edilmesi, Yunan ordusunun elinde bulunan Türk esirlerin derhal serbest birakılması, Trakya'nın derhal tahliye edilerek, Türk Hükûmetine teslim edilmesi, eğer bu sağlanmazsa ordulara harekât emri verilmesi talimatını alan İsmet Paşa, 1. ve 2. orduların Kocaeli ve Çanakkale istikametinde harekete geçirilmesini emretmiştir. ${ }^{157} \mathrm{Bu}$ durum İngiliz ve Fransızları telaşlandırmış ve görüşmelere 7 Ekim'den 9 Ekim'e kadar ara verilmiştir. ${ }^{158}$

Zaman zaman gergin anların yaşandığ 1 , hatta görüşmelerin kesilmesi tehlikesinin doğduğu ve Türk Ordusunun yeniden harekât hazırlıklarına giriştiği mütareke görüşmeleri 11 Ekim'de uzlaşmayla sonuçlanmıştır. Burada, Türk-Yunan savaşının 14-15 Ekim gece yarısından itibaren bitmiş sayılacağı, Yunan güçlerinin Doğu Trakya'yı 15 gün içinde boşaltacakları, ${ }^{159}$ İstanbul ve boğazların yönetim şeklinin yapılacak barışta saptanacağı, İtilaf devletleri askerlerinin bulundukları yerlerden ancak barış yapıldıktan sonra çıkacakları gibi kararlar alınmıştır. ${ }^{160}$

Aynı gün Antlaşma maddelerinin Türkiye Büyük Millet Meclisi’nde okunması üzerine söz alan Dışişleri Bakanı Yusuf Kemal Bey, "Bu mukavele-i askeriye ile Misak-ı Millîmizin tamama tahakkukuna doğru bir adım atılmış oluyor... Bir buçuk ay sonra, zulüm ve işkence altında inleyen Trakya'mız kurtulacak, Büyük Millet Meclisi'nin idaresi altına girecektir"'161 ifadelerini kullanırken Hâkimiyet-i Millîye Gazetesi'ndeki haberde de Büyük Zafer'in siyasi kazanımlarının Türkiye tarafından birer birer kullanılmaya başlandığı ve Mudanya'daki sonucun

156 Şerafettin Turan, İsmet İnönü Yaşamı, Dönemi ve Kişiliği, 2. Baskı, (Ankara: Bilgi Yayınevi, 2003), 49.

157 Selek, İsmet İnönü, 306-308.

158 Konferans ve tartışma konuları ile ilgili detaylı bilgi için bkz. İsmail Eyyüpoğlu, "Mudanya Mütarekesi (Yapılan Teklifler, Görüşmeler Alınan Kararlar)", (Yüksek Lisans Tezi, Erzurum Atatürk Üniversitesi 1998).

159 Trakya'nın Yunan kuvvetlerinden boşaltılması ve Türk tarafına teslimi ile ilgili süre daha önce 45 gün olarak teklif edilirken, anlaşmada 15 güne indirilmiştir. Bütün Trakya'nın Türkiye'ye teslimi ise 30 gün içinde gerçekleştirilecektir. Selek, İsmet İnönü, 310.

160 Hüseyin Avni Çavdaroğlu, Öncesi ve Sonrası İle Lozan (İstanbul: Yeditepe Yayınevi, 2011), 57-58.; Ayrıca bkz. Karacan, Lozan Konferanst ve İsmet Paşa, 33. ; Anlaşma maddeleri ertesi gün, 12 Ekim 1922'de Hâkimiyet-i Milliye, Sabah gibi dönemin gazetelerinde de yayınlanmıştır.

161 TBMM Zabit Ceridesi, 11 Ekim 1922, 23: 345-351. 
bir meydan muharebesi zaferinden daha büyük olduğu vurgulanmıştır. ${ }^{162}$ Zira Trakya Bölgesi savaş yapılmadan Türkiye'ye iltihak etmiştir.

\subsection{Lozan Barışı ve Anadolu İhtilalinin Tescili}

Mudanya Mütarekesi'nin hemen ardından görüşmelerini sıklaştıran İtilaf Devletleri, barış konferansının 13 Kasım'da İsviçre'nin Lozan şehrinde toplanacağını kararlaştırmışlar ve bunu 27 Ekim tarihli bir notayla hem TBMM hem de İstanbul hükûmetlerine bildirmişlerdir. ${ }^{163}$ Böylece büyük Türk zaferinin ardından sıra Lozan'da barışın sağlanması ve yeni Türk devletinin tüm dünyaya tanıtılmasına gelmiştir. Türk tarafı Heyet Başkanı olarak "memleketin en liyakatli çocuğu" olarak tanımlanan İsmet Paşa'yı seçerken, ${ }^{164}$ İtilaf devletlerinin hem TBMM hem de İstanbul hükûmetine aynı anda davet göndermesi ise Türk milletinin hangi hükûmet tarafından temsil edileceği meselesini ortaya çıkarmıştır. Ancak Mustafa Kemal Paşa’nın Türk milletinin asıl temsilcisinin TBMM olduğunu beyan etmesinin ardından, İstanbul Hükümeti'nin konferansa birlikte katılmak ve konferansta takip edilecek ilkeleri belirlemek amaciyla bir temsilci gönderilmesini talep etmesi Meclis’i harekete geçirmiştir. Doktor Rıza Nur, çok uzun yıllardır düşünüp tasarladığı din ile devleti birbirinden ayırma, dolayısıyla lâik bir devlet yaratma firsatını bulmuştur. ${ }^{165} \mathrm{O}$ 'nun hazırladığ 1 ve 81 mebusun imzalarını taşıyan ve Osmanlı Saltanatının İstanbul'un işgal edildiği 16 Mart 1920'de sona erdiğini öngören teklif, üzerinde değişiklik yapılarak 1 Kasım 1922'de kabul edilmiştir. ${ }^{166}$ Karar, 2 Kasım'da TBMM İstanbul temsilcisi Refet Paşa tarafından Sultan Vahdettin'e bildirilmiştir.

Meclis'in aldığı bu kararla iktidarda ancak dört gün daha kalabilen İstanbul Hükûmeti, aynı zamanda İstanbul'da bulunan İngiliz ve Fransız Yüksek Komiserlerinden de yardım talebinde bulunmuştur. Talepleri karşılık bulmayan Tevfik Paşa, 5 Kasım 1922'de görevini 19 Ekim'de İstanbul'a gelen TBMM temsilcisi Refet Paşa'ya devretmiştir. İstanbul Hükûmeti Dışişleri Bakanı Ahmet İzzet Paşa ise İngiliz Yüksek Komiseri Sir Horace Rumbold'a Türklerin Yunanlılara karşı kazandığı zaferden üzüntü duyduğunu belirtmiştir. Öte yandan Sultan Vahdettin de İngilizlerden yardım talep etmiş, ${ }^{167}$ bunun üzerine TBMM Hükümeti, Vahdettin'in hilafet makamından düşürülmesine ve yapılan seçim sonunda Şehzade Abdülmecit Efendi’nin yeni halife olarak hilafet makamına oturmasına karar vermiştir. ${ }^{168}$ Sonrasında ise General Harrington’un ifadesiyle: “17 İkinciteşrin 1922’de, Zatı Şahane (yani Sultan) İngiltere’nin himayesi altına girip, İstanbul'u bir İngiliz harp gemisiyle terk etmişlerdir.”169

162 "Zaferden Zafere”, Hâkimiyet-i Milliye, 12 Ekim 1922.

163 Salâhi R. Sonyel, “Lozan'da Türk Diplomasisi (Eylül 1922-Ağustos 1923)”, Bellete, XXXVIII/149 (1974), 41-116.

164 M. Cemil Bilsel, Lozan (İstanbul: Soysal Yayınları, 1998), 2: 4.

165 Rıza Nur, Lozan Hatıratı, 3. Baskı, (İstanbul: Boğaziçi Yayınları, 1992), 26-28.

166 TBMM Zabit Ceridesi, 1 Kasim 1922, 24: 313-330.

167 Sonyel, “Lozan'da Türk Diplomasisi (Eylül 1922-Ağustos 1923)”, 41-116.

168 Taha Akyol ve Sefa Kaplan, Açık ve Gizli Oturumlarda Lozan Tartışmaları, TBMM'de Lozan Müzakereleri Tutanaklarl (İstanbul: Doğan Kitap, 2013), 209.

169 Atatürk, Nutuk, 469. ; Afet İnan, “Türk İstiklâli ve Lozan Muahedesi”, Belleten 2/7-8 (1938), $277-307$. 
Bu durum Osmanlı İmparatorluğu'nun hukuki anlamda sonu ve Lozan'da Türkiye'yi Ankara Hükümeti'nin temsil edeceği anlamlarına gelmekteydi. ${ }^{170}$ Bunun üzerine Meclis, 2 Kasım 1922'de İsmet Paşa'nın Başmurahhaslığı ile birlikte, Sağlık Bakanı Doktor Rıza Nur ve Maliye Bakanı Hasan (Saka) Bey’in de murahhaslıklarını onaylamıştır. ${ }^{171}$ İsmet Paşa ertesi gün Meclis’te sık sık Misak-1 Millı̂’ye atıfta bulunarak, Lozan Delegasyonunun Konferansta izleyeceği yolu açıklamıştır. ${ }^{172}$ Heyet, 4 Kasım'da Ankara'dan yola çıkmış, 11 Kasım'da Lozan'a varmıştır. Fransız Hükümeti'nden beklenmeyen bir davet alan İsmet Paşa, ertesi gün barışın olup olmayacağını öğrenebilmek için Paris’e gitmiştir. Burada üst düzey temaslarda bulunan Paşa, en azından Fransızların barıştan yana olduğunu anlamıştır. ${ }^{173}$

Lozan Konferansı'na Sovyet Rusya; Boğazlar, Bulgaristan; Boğazlar ve sınırlar, İsveç, Norveç, Felemenk, Danimarka, İspanya ve Belçika; kapitülasyonlar müzakerelerine katılmak için gelmişlerdir. Bunların dışında kendi istek ve dileklerini aktarmak üzere Lozan'a gelenler olmuştur. ${ }^{174} 20$ Kasım'da açılan Konferansta İngiltere'yi Lord Curzon, Sir Horace Rumbold, Andrew Ryan ve Sir Adam Block temsil ederken, Fransızları Barrere ve Bompard; İtalyanları Garroni ve Montagna, Yunanlıları ise Eleftherios Venizelos temsil etmiştir.

İsviçre Cumhurbaşkanı'nın sulh temennisi ve barış dilekleriyle yaptığı açılış konuşmasından sonra Lord Curzon da bir konuşma yapmıştır. Hemen arkasından ise İsmet Paşa söz alarak “... Sulhun nimetlerinden daima mahrum kalan Türk milleti, hak ve adalet istihsali için yaptı̆̆ mükerrer sulh teşebbüslerinin kifayetsizliğini ve faidesizliğini idrak ederek, artık hiçbir kurtuluş ümidi kalmadığını anlayarak, varlığını korumaya ve maddi manevi kendi vasıtalarıyla istiklalini sağlamaya muvaffak oldu" ifadelerini kullandıktan sonra, bir milyondan fazla masum Türk'ün Küçük Asya' da evsiz ve ekmeksiz dolaştıklarından bahsetmiştir. ${ }^{175}$ Paşa'nın bu söylevi müttefikler arasında iyi tesir yapmamış, aksine Türklere karşı besledikleri düşmanlıklarını daha da kamçılamıştır. Bu bağlamda Curzon, konferansın her aşamasının gergin geçeceği tahmininde bulunmuş, Türk tarafının isteklerinin derhal reddedilmesi de bu tahmini doğru çıkarmıştır. ${ }^{176}$

Lozan Konferansı'nda sınırlar, azınlık meseleleri, iktisadi ve mali meseleler gibi belli başlı konular görüşülmüştür. Türk heyetinin Misak-1 Millî’den taviz vermeyeceğini göstermesi, görüşmelerin kesintiye uğramasına sebep olsa da 24 Temmuz 1923 tarihinde imzalanan antlaşmayla yeni Türk devletinin resmen ilanı gerçekleşmiştir. Artık Misak-1 Millî sınırları içerisinde, Türk milletinin Türkiye Cumhuriyeti Devleti adıyla varlığını sürdüreceği ve tam bağımsızlık ülküsünden asla ödün vermeyeceği anlaşılmıştır.

170 İnan, “Türk İstiklâli ve Lozan Muahedesi”, 277-307.

171 Sonyel, “Lozan'da Türk Diplomasisi (Eylül 1922-Ağustos 1923)”, 41-116.

172 Konuşma için bkz. İsmet İnönü, Lozan Barış Konferansı Konuşma, Demeç, Makale, Mesaj, Anı ve Söyleşileri, haz. İlhan Turan, (Ankara: Atatürk Araştırma Merkezi Yayını, 2010), 11.

173 İsmet İnönü, “İstiklal Savaşı ve Lozan”, Belleten XXXVIII/149 (1974), 1-30.

174 BCA, 30.10/117.817.13. lef. 8-9.

175 Selek, Ísmet İnönü, s. 330-331.

176 Sonyel, “Lozan’da Türk Diplomasisi (Eylül 1922-Ağustos 1923)”, 41-116. 


\section{Sonuç}

Birinci Dünya Savaşı, bir taraftan Avrupa ve Asya'da devletler arası dengeleri değiştirmiş diğer taraftan da çok uluslu imparatorlukların dağılmasına ve yeni bir dünya düzeninin kurulmasına zemin hazırlamıştır. Osmanlı Devleti de tıpkı Avusturya-Macaristan ya da Rusya gibi çok uluslu bir yapıya sahip olduğu için savaşın sonuçlarından en fazla etkilenen devletlerin başında gelmiştir. Savaşın galipleri yeni bir düzen kurma konusunda son derece sabırsız davranırlarken mağlup devletler bu durumdan en az zararla çıkmanın yollarını aramışlardır. İmzalanan ateşkes antlaşmaları savaşın bittiğini resmileştirirken kalııı barışın sağlanması için uzun bir süreye daha ihtiyaç duyulmuştur. Zira Osmanlı Devleti'nin imzaladığı Mondros Ateşkes Antlaşması devletin varlı̆ı̆ını fiilen sona erdirmiş ve savaş ortamından kolay kolay çıkılamayacağı herkes tarafindan bir kez daha görülmüştür.

Mondros Mütarekesi ve hemen ardından başlayan işgaller karşısında tepkisiz kalmayan Türk milleti, vatansız yaşamaktansa savaşmayı tercih etmiş ve oluşturulan Kuva-yı Millîye teşkilatlarıyla işgal güçlerine karşı önemli bir mücadeleye girişmiştir. Bu sırada İngilizlerin desteğiyle Yunan güçlerinin İzmir'i işgalleri ise bardağı taşıran damla olmuş ve işgal tüm yurtta protesto edilmiştir. Karadeniz civarında asayişi sağlamakla görevlendirilen Mustafa Kemal Paşa ise aynı anlayışın tüm yurda yayılması için Millî Mücadele hareketini başlatmıştır. Anadolu'nun çeşitli yerlerinde düzenlediği kongre ve mitinglerle halkın bilinçlenmesini sağlayan Mustafa Kemal Paşa, bir taraftan İtilaf Devletleri, diğer taraftan da İstanbul hükümeti için bir tehdit unsuru olmaya başlamıştır. Zaten işgallere karşı çıkarak ve bu işgaller karşısında İstanbul hükümetinin üzerine düşeni yapmadığını söyleyerek Mustafa Kemal Paşa her iki tarafa da meydan okumuştur.

Erzurum Kongresi'yle oluşturulan Heyet-i Temsiliye ve İstanbul'un işgalinden sonra Ankara'da kurulan Türkiye Büyük Millet Meclisi, Millî Mücadele hareketinin askerî ve diplomatik safhalarını başarıyla yürütürken, büyük oranda düşman işgaline uğramış Türk topraklarında yeni bir devlet kurma fikrini başından itibaren ilan etmekten de çekinmemiştir. TBMM ve onun düzenli ordusunun kazandığı önemli başarılar İtilaf Devletleri’ni, özellikle de Fransa'y1, Ankara'ya yanaştırmış ve Türk milletine kabul ettirilemeyen Sevr metni üzerinde birtakım değişiklikler vaat edilerek Ankara hükümeti barış yapmaya zorlanmıştır. Bunun için Londra'da tekrar bir konferans toplayan İtilaf Devletleri, buraya hem İstanbul hükümeti hem de Ankara hükümeti temsilcilerini davet etmiştir. Bu durumdan faydalanmak isteyen İtilaf Devletleri umduklarını bulamadıkları gibi artık kendi aralarındaki birliğin de dağılmaya başladığını görmüşlerdir. Bu husus Mustafa Kemal Paşa'nın da gözünden kaçmamış ve İngiltere'yi Fransa karşısında yalnız bırakmak için hızlı bir şekilde Fransızlarla temas kurulmuştur. TBMM hükümeti ile Fransa arasında imzalanan Ankara İtilafnamesi Millî Mücadele döneminin ilk büyük diplomatik başarısı olarak kabul edilirken arık ihtilalin, yani kurtuluşun yakın olduğu görülmüştür. Sakarya ve Başkomutanlık Meydan Muharebelerinin sonucunda Anadolu'da tutunamayacağını anlayan İtilaf Devletleri, önce ateşkes sonra da barış için masaya oturmak 
mecburiyetinde kalmışlardır. Nihayet Türk tarafı beş yıl önce mağlup olarak terk ettiği masaya bu defa galip devlet sıfatıyla oturmuş ve millî sınırlar içerisinde bağımsız bir Türk devletinin kuruluşu Lozan'da tüm dünyaya ilan edilmiştir.

Lozan Konferansı'nda Türk tarafı adına çözüme kavuşturulan ve ileriki bir tarihte çözülmek üzere ertelenen meseleler olmuş, bu meseleler Cumhuriyet'in ilk döneminde iç ve dış politikanın ilkesel olarak yönünü belirlemiştir. Buna, Azınlık okullarının Maarif Vekâleti’ne bağlanması, nüfus mübadelesinin gerçekleştirilmesi, Irak sınırının belirlenmesi, Boğazların yeni statüye kavuşturulması, Hatay’ın Türkiye'ye iltihakı, Osmanlı borçlarının taksimi ve ödenmesi gibi meseleler örnek olarak gösterilebilir.

Sonuç olarak, Mondros Mütarekesi ile başlayıp Sevr Anlaşması ile Türk toprakları üzerindeki emellerini kabul ettirmek isteyen emperyalist devletler, Türk milletinin haklı direnişi karşısında başarıya ulaşamamıştır. Savaş meydanlarında gösterilen bağımsızlık arzusu ve mücadele ruhu, diplomasi sahasında da kendisini hissettirmiş ve tam bağımsızlık ülküsü etrafında birleşen millet, bağlattığı ihtilal hareketini aynı kararlılıkla sürdürmüştür.

\section{Kaynaklar}

\section{Arşiv Belgeleri}

\section{Başbakanlık Cumhuriyet Arşivi}

BCA, 030.18.1.1/1.3.15

BCA, 30.10/54.354.4

BCA, 30.10/54.354.11

BCA, 30.18.1.1/6.47.9

BCA, 30.10/204.394.28

BCA, 30.18.1.1/2.33.9

BCA, 30.18.1.1/2.33.14

BCA, 30.18.1.1/2.33.15

BCA, 30.10/117.817.13

\section{Resmi Yayınlar}

Düstur, Üçüncü Tertip, 2. cilt, Milliyet Matbaas1, İstanbul 1929.

Meclis-i Mebusan Zabit Ceridesi, 1. cilt, 17 Şubat 1336 (1920).

TBMM Gizli Celse Zabıtları, 1. cilt, 24 Nisan 1920.

TBMM Gizli Celse Zabitlarl, 1. cilt, 1 Mayıs 1920.

TBMM Gizli Celse Zabıtları, 1. cilt, 29 Mayıs 1920.

TBMM Gizli Celse Zabitlarl, 1. cilt, 4 Şubat 1921.

TBMM Gizli Celse Zabitları, 1. cilt, 17 Mart 1921. 
TBMM Gizli Celse Zabitlarl, 2. cilt, 12 Mayıs 1921.

TBMM Gizli Celse Zabitlarl, 2. cilt, 5 Ağustos 1921.

TBMM Gizli Celse Zabitlart, 3. cilt, 6 Mayıs 1922.

TBMM Zabut Ceridesi, 1. cilt, 24 Nisan 1920.

TBMM Zabit Ceridesi, 2. cilt, 22 May1s 1920.

TBMM Zabut Ceridesi, 3. cilt, 19 Ağustos 1920.

TBMM Zabit Ceridesi, 23. cilt, 11 Ekim 1922.

TBMM Zabit Ceridesi, 24. cilt, 1 Kasım 1922.

\section{Gazeteler}

Hâkimiyet-i Millîye

\section{Telif Eserler}

Ahmet İzzet Paşa. Feryadım. Yayına Hazırlayan Süheyl İzzet Furgaç-Yüksel Kanar. 2. Baskı. İstanbul: Timaş Yayınları, 2017.

Akyol, Taha ve Sefa Kaplan. Açık ve Gizli Oturumlarda Lozan Tartışmaları, TBMM’de Lozan Müzakereleri Tutanaklart. İstanbul: Doğan Kitap, 2013.

Ataöv, Türkkaya. "Filistin Sorununun Ardındaki Gerçek: İsrail'in Kuruluşuna Kadar", Ankara Üniversitesi SBF Dergisi 25/3 (1970): 29-66.

Atatürk, Kemal. Nutuk. Yayına Hazırlayan Zeynep Korkmaz. Ankara: Atatürk Araştırma Merkezi Yayınları, 2006. Atatürk’ün Söylev ve Demeçleri. Yayına Hazırlayan Ali Sevim, İzzet Öztoprak, Akif Tural. Ankara: Atatürk Araştırma Merkezi Yayınları, 2006.

Bayar, Celal. Ben De Yazdım. Millî Mücadeleye Gidiş 1. İstanbul: Sabah Kitapları, 1997.

Baykal, Bekir Sıtkı. Erzurum Kongresi İle İlgili Belgeler. Ankara: Türk İnkılâp Tarihi Enstitüsü Yayınları, 1969. Baykal, Bekir Sitkı. Heyet-i Temsiliye Kararları. Ankara: TTK Basımevi, 1974.

Bayur, Yusuf Hikmet. Türk Inkılâbı Tarihi. 3. Cilt, 4. Kısım. Ankara: TTK Yayınları, 1983.

Bayur, Yusuf Hikmet. Türkiye Devleti’nin Dış Siyasası. Ankara: TTK Yayınları, 1973.

Belen, Fahri. Türk Kurtuluş Savaşı. Ankara: Kültür ve Turizm Bakanlığı Yayınları, 1983.

Bıyıklığlu, Tevfik. "Başkumandan Atatürk'ün Kısa Bir Portresi”, Belleten XX/80 (1956): 701-735.

Bilsel, M. Cemil. Lozan. Cilt 1-2. İstanbul: Soysal Yayınları, 1998.

Cebesoy, Ali Fuat. “Mustafa Kemal-Millî Lider”, Belleten XX/80 (1956): 549-555.

Cebesoy, Ali Fuat. Millî Mücadele Hatıralart. İstanbul: Temel Yayını, 2000.

Çavdaroğlu, Hüseyin Avni. Öncesi ve Sonrası İle Lozan. İstanbul: Yeditepe Yayınevi, 2011.

Dilek, Mehmet Sait ve Evren Küçük, “San Remo Konferansı'nda İngiltere'nin Ermeni Politikası (18-26 Nisan 1920)", Turkish Studies 7/3 (2012): 959-971.

Erim, Nihat. Devletlerarası Hukuku ve Siyasi Tarih Metinleri. 1. cilt, Ankara: Ankara Üniversitesi Hukuk Fakültesi Yayınları, 1953. 
Eyyüpoğlu, İsmail. “Mudanya Mütarekesi (Yapılan Teklifler, Görüşmeler Alınan Kararlar)”, (Yüksek Lisans Tezi, Erzurum Atatürk Üniversitesi), 1998.

Ezherli, İhsan. Türkiye Büyük Millet Meclisi (1920-1992) ve Osmanlı Meclis-i Mebusanı (1877-1920). Ankara: TBMM Kültür, Sanat ve Yayın Kurulu Yayınları, 1992.

Harp Tarihi Vesikaları Dergisi, 1/1, Ankara: Genelkurmay Basımevi, 1952.

Irmak, Sadi. Atatürk Devrimleri Tarihi. İstanbul: Fatih Yayınevi, 1973.

İğdemir, Uluğ. Heyet-i Temsiliye Tutanakları. 2. Baskı. Ankara: TTK Basımevi, 1989.

İğdemir, Uluğ. Sivas Kongresi Tutanakları. Ankara: TTK Yayınları, 1986.

İnan, Afet. "Türk İstiklâli ve Lozan Muahedesi”, Belleten 2/7-8 (1938): 277-307.

İnönü, İsmet. "Devlet Kurucusu Atatürk”, Belleten XXXIII/129 (1969): 1-19.

İnönü, İsmet. "İstiklal Savaşı ve Lozan”, Belleten XXXVIII/149 (1974): 1-30.

İnönü, İsmet. Defterler (1919-1973). 1. cilt. Hazırlayan Ahmet Demirel. 3. Bask1. İstanbul: Yapı Kredi Yayınları, 2008.

İnönü, İsmet. Lozan Barış Konferansı Konuşma, Demeç, Makale, Mesaj, Anı ve Söyleşileri. Hazırlayan İlhan Turan. Ankara: Atatürk Araştırma Merkezi Yayını, 2010.

Karabekir, Kâzım. İstiklâl Harbimiz. 1. Cilt. 2. Baskı, İstanbul: Yap1 Kredi Yayınları, 2008.

Karacan, Ali Naci. Lozan Konferansı ve İsmet Paşa. 3. Baskı. Ankara: Bilgi Yayınevi, 1993.

Karaosmanoğlu, Yakup Kadri. Vatan Yolunda. İstanbul: İletişim Yayınları, 1999.

Karpat, Kemal H. Türkiye'de Siyasal Sistemin Evrimi 1876-1980, Çeviren Esin Soğancılar, İmge Kitabevi, Ankara 2007.

Kodaman, Bayram. Ermeni Macerast. Isparta: Süleyman Demirel Üniversitesi Yayınları, 2001.

Köse, İsmail. "Paris Barış Konferansı Tutanakları ve Başkan Woodrow Wilson'un Türk Algısı", History Studies 6/3 (2014): 217-238.

Kurat, Yuluğ Tekin, "Mustafa Kemal's İnstructions (An İntercepted and Decyphered Telgram) to Bekir Sami in London-A Reassessment of the London Conference (21 February-12 March 1921) and its İmmediat Consequences", Belleten XLVIII/189-190 (1984): 55-88.

Küçük, Cevdet. "Misâk-i Millı̂”, İslam Ansiklopedisi. Ankara: TDV Yayınları, 2005, 30: 173-175.

Küçük, Cevdet. "Şark Meselesi Hakkında Önemli Bir Vesika”, I.Ü. Edebiyat Fakültesi Tarih Dergisi 32 (1979): 607-638.

Milli Egemenlik Belgeleri. Ankara: TBMM Basımevi, 2015.

Mumcu, Ahmet. "Misâk-1 Millî ve Anayasamız”, Atatürk Araştırma Merkezi Dergisi 1/3 (1985): 813-830.

Narinç, Ökkeş. “Birinci Dünya Savaşı'nda Bulgaristan ve Osmanlı Devleti Arasında Kurulan Güdümlü İttifak'ın Sona Ermesi”, Mondros Mütarekesi'nin 100. Ylll: I. Dünya Savaşı'nın Sonu, Mütarekeler ve Barış Andlaşmaları içinde, 1-2:207-226. Ankara: Atatürk Araştırma Merkezi Yayınları, 2019.

Narinç, Ökkeş. “1919-1920 Yıllarında Müfettişlik Müessesesi”, Asia Minor Studies Dergisi 1/1 (2013): 77-93.

Nur, Rıza. Lozan Hatıratı. 3. Baskı İstanbul: Boğaziçi Yayınları, 1992.

Özalp, Kâzım. Millî Mücadele. 1. Cilt. 4. Baskı. Ankara: TTK Yayınları, 1998.

Özgül, Cemil. Heyet-i Temsiliye'nin Ankara 'daki Çalışmaları (27 Aralık 1919-23 Nisan 1920). Ankara: Atatürk Araştırma Merkezi Yayınları, 1989. 
Öztoprak, İzzet. "Londra Konferansı ve Türkiye Meselesinin Cereyan-1 Müzakeratı", Atatürk Araştırma Merkezi Dergisi XI/33 (1995): 565-612.

Selek, Sebahattin. Anadolu İhtilali. 1. cilt. İstanbul: Kastaş Yayınevi, 2010.

Selek, Sebahattin. İsmet İn̈nü, Hatıralar. 1. cilt. İstanbul: Bilgi Yayınevi, 1985.

Sonyel, Salâhi R. “İngiliz Yüksek Komiseri Sir Horace Rumbold’un Türk Ulusal Akımına Karşı Tutumu (1920-1923)”, Belleten LVII/221 (1994): 159-184.

Sonyel, Salâhi R. “Lozan'da Türk Diplomasisi (Eylül 1922-Ağustos 1923)”, Belleten XXXVIII/149 (1974): $41-116$. Sonyel, Salâhi R. Mustafa Kemal (Atatürk) ve Kurtuluş Savaşı. 1. cilt. Ankara: TTK Yayınları, 2008.

Sonyel, Salâhi R. Türk Kurtuluş Savaşı ve Dış Politika. 1. cilt. 2.Baskı. Ankara: TTK Yayınları, 1987.

Sonyel, Salâhi R. Türk Kurtuluş Savaşı ve Dış Politika. 2. cilt. 2. Baskı. Ankara: TTK Yayınları, 1991.

Soysal, İsmail. Tarihçeleri ve Açıklamaları İle Birlikte Türkiye ’nin Siyasal Andlaşmaları. 1. cilt. (1920-1945). Ankara: TTK Yayınları, 1983.

Şahin, İsmail, Cemile Şahin ve İsmail Şükür. “Ortadoğu'da Emperyalist Güçlerin Gizli Oyunu: Sykes-Picot Antlaşması", The Journal of Academic Social Science Studies 38 (2015): 241-262.

Şimşir, Bilal N. Malta Sürgünleri. Ankara: Bilgi Yayınevi, 1985.

Tansel, Selâhattin. Mondros 'tan Mudanya'ya Kadar. 1. cilt. Ankara: MEB Yayınları, 1977.

Tansel, Selâhattin. Mondros 'tan Mudanya'ya Kadar. 2. cilt. Ankara: MEB Yayınları, 1978.

Tansel, Selâhattin. Mondros 'tan Mudanya 'ya Kadar. 3. cilt. Ankara: MEB Yayınları, 1978.

Tansel, Selâhattin. Mondros 'tan Mudanya'ya Kadar. 4. cilt. Ankara: MEB Yayınları, 1978.

Tunaya, Tarık Zafer. "Türkiye Büyük Millet Meclisi Hükümetinin Kuruluşu ve Siyasi Karakteri”, I.H.F.M. 23/3-4: 227-247.

Turan, Mustafa. Siyasi ve Hukuki Açıdan Millî Mücadele (30 Ekim 1918-24 Temmuz 1923). 2. Bask1. Ankara: Berikan Yayınevi, 2014.

Turan, Şerafettin. Ísmet İnönü Yaşamı, Dönemi ve Kişiliği. 2. Baskı. Ankara: Bilgi Yayınevi, 2003.

Türk İstiklal Harbi. Batı Cephesi, 2. cilt. 1. Kısım. Ankara: Genelkurmay Basımevi, 1994.

Türk Istiklal Harbi. Batı Cephesi, 2. cilt. 2. Kısım. 3. Baskı. Ankara: Genelkurmay Basımevi, 1999.

Türk Istiklal Harbi. Batı Cephesi, 2. cilt. 3. Kısım. 3. Baskı. Ankara: Genelkurmay Basımevi, 1999.

Türk Istiklal Harbi. Batı Cephesi, 2. cilt. 5. Kısım. 2. Kitap. Ankara: Genelkurmay Basımevi, 1973.

Türk Ístiklal Harbi. Doğu Cephesi (1919-1921), 3. cilt. Ankara: Genelkurmay Basımevi, 1995.

Türk Istiklal Harbi. Güney Cephesi, 4. cilt. Ankara: Genelkurmay Basımevi, 2009.

Türk Istiklal Harbi. Mondros Mütarekesi ve Tatbikatı, 1. cilt. 3. Bask1. Ankara: Genelkurmay Basımevi, 1999.

Türkgeldi, Ali. Moudros (Mondros) ve Mudanya Mütarekelerinin Tarihi. Ankara: Türk Devrim Tarihi Enstitüsü Yayınlar1, 1948.

Velidedeoğlu, Hıfzı Veldet. İlk Meclis. İstanbul: Cumhuriyet Yayınları, 1999.

Yalçın, Durmuş vd. Türkiye Cumhuriyeti Tarihi. 1. cilt. Ankara: Atatürk Araştırma Merkezi Yayını, 2005.

Yavuz, Bige. “1921 Tarihli Türk-Fransız Anlaşması”, Atatürk Araştırma Merkezi Dergisi VIII/23 (1992): 273 -308.

Yavuz, Bige. Kurtuluş Savaşı Döneminde Türk-Fransız İlişkileri. Ankara: TTK Yayınları, 1994.

Zurcher, Erik Jan. Terakkiperver Cumhuriyet Fırkası. İstanbul: Bağlam Yayınları, 1992.

100. Yılında 1919 Arşivimizden Belgeler. Ankara: Dışişleri Bakanlığı Diplomatik Arşiv Dairesi Başkanlığı, 2019. 
